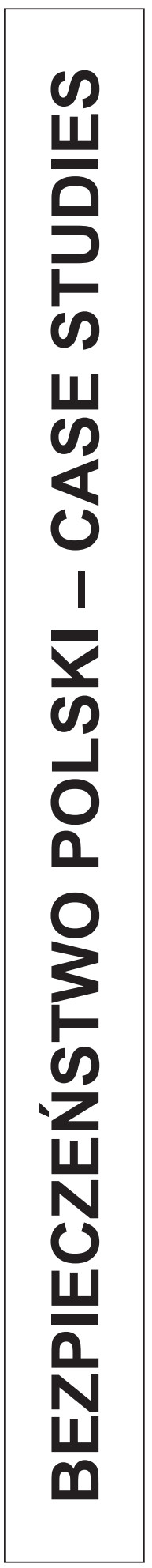





\section{MNIEJSZOŚCI NARODOWE A BEZPIECZEŃSTWO POLSKI}

Problem mniejszości narodowych, a także politycznych, językowych i rasowych ciągle zajmuje uwagę socjologów, polityków, kulturoznawców i politologów. Fakt, że zagadnienie to jest przedmiotem zainteresowań wielu dyscyplin powoduje znaczące zamieszanie terminologiczne w zakresie podstawowych kategorii tego pola badawczego. W literaturze, a w pierwszym rzędzie - socjologicznej, spotyka się wiele klasyfikacji i typologii grup mniejszościowych. Najczęściej podstawą wyróżnienia mniejszości jest rodzaj integracji grupy mniejszościowej. Wskazuje się przy tej okazji mniejszości wyodrębnione ze względu na kryteria: terytorialno-kulturowe, kulturowo-ideologiczne, biologiczne, fizjologiczne, psychiczne, wreszcie mniejszości mające charakter grup interesów. Najczęściej podstawą wyróżnienia mniejszości są: język, zwyczaje, styl życia, tradycje. Wiąże się z tym najczęściej kryterium terytorialne, gdyż tego typu mniejszości bardzo często, choć nie zawsze, zamieszkują określone terytorium, w obrębie jednego lub kilku państw (Sobczak, 2003: 25-61; Rokkan, 1983; Minderheiten, 1974; Walter, 1952: 31).

Wypada zauważyć, że mniejszości narodowe są kategorią, którą od wielu lat stara się określić społeczność międzynarodowa (Sobczak, 2008: 9-43; Sobczak, 2003: 25-62; Mikołajczyk, 1960: 15; Mik, 1996: 19-23; Byczkowski, 1977: 340; Suchocka, 1991: 143; Les droits, 1997: 41; Szczepaniak, 1995: 101; Higgins, 1994: 193; Thomberry, 1991; Radley, 1995: 48; Barcz, 1986: 91). Próbę sformułowania definicji mniejszości narodowych podjęto w rekomendacji 1134/1990 Zgromadzenia Parlamentarnego Rady Europy w sprawie praw mniejszości. W dokumencie stwierdzono, że pojęcie „mniejszości” odnosi się od obywateli państwa o długim rodowodzie, stanowiących grupę „dobrze określoną zadomowioną na terytorium państwa, której członkowie są obywatelami tego państwa i mają pewne religijne, językowe i kulturowe lub inne cechy charakterystyczne odróżniające ich od większości populacji” (Recommendation, 1990). Próbę sformułowania definicji mniejszości podjęła także Europejska Komisja Demokracji przez Prawo (ang. European Commission on Democracy Through Law), zwana także Komisja wenecka. W projekcie konwencji o ochronie mniejszości zdefiniowała mniejszości jako ,grupę mniejszą liczebnie od reszty populacji państwa, której członkowie - będący obywatelami tego państwa - posiadają etniczne, religijne lub językowe cechy różne od tych charakterystycznych dla pozostałej populacji i którzy kierują się wolą zachowania własnej kultury, tradycji, religii lub języka" (European, 2002). W artykule 1 Instrumentu o ochronie praw mniejszości inicjatywy środkowoeuropejskiej, otwartego do podpisu w Turynie 19 listopada 1994 r. stwierdzono, że mniejszość narodowa oznacza ,grupę liczebnie mniejszą od pozostałej części ludności w danym pań- 
stwie, której członkowie, będący obywatelami danego państwa, mają etniczne religijne i językowe cechy odróżniające ich od pozostałej części ludności i kierują się wolą zachowania własnej tradycji, religii i języka" (Janusz, Bajda, 2000a: 61; Sozański, 2002: 24). Problem ochrony mniejszości narodowych podjęto także w Konwencji ramowej o ochronie mniejszości narodowych sporządzonej w Strasburgu 1 lutego 1995 r. ${ }^{1}$, a parę miesięcy później w Europejskiej Karcie Języków Regionalnych lub Mniejszościowych, sporządzonej w Strasburgu 5 listopada 1995 r. ${ }^{2}$ (Sobczak, 2009: 25-49).

Nie wypracowano żadnych kryteriów pozwalających rozróżnić naród od mniejszości narodowych bądź etnicznych. Najrozsądniejsze wydaje się przyjęcie tezy, iż mniejszość narodowa to taka część ludności państwa, która legitymując się własną kulturą, przeświadczeniem o wspólnym pochodzeniu, często językiem, religią i zamieszkująca (ale nie zawsze) wspólne terytorium, różni się od narodu tworzącego określone państwo. Oczywiście, teza ta okaże się nieprawdziwa lub nie do końca prawdziwa w odniesieniu do państw wielonarodowych.

W art. 35 Konstytucji z 1997 r. Rzeczpospolita Polska zapewniła obywatelom polskim należącym do mniejszości narodowych i etnicznych wolność zachowania i rozwoju swojego języka, obyczajów i tradycji oraz rozwoju własnej kultury (art. 35 ust. 1). Zagwarantowano także, iż mniejszości narodowe i etniczne mają prawo do tworzenia własnych instytucji edukacyjnych, kulturalnych oraz służących tożsamości religijnej,

1 Konwencja została ratyfikowana przez Polskę 10 listopada 2000 r. (Dz. U. 2002, Nr 22, poz. 209). Konwencja ramowa nie zawiera definicji mniejszości narodowej, dlatego też Polska, ratyfikując tę konwencję, oświadczyła, że pod terminem mniejszość narodowa rozumie „mniejszości narodowe zamieszkałe na terytorium Rzeczypospolitej Polskiej, której członkowie są obywatelami polskimi”. Tego rodzaju stwierdzenie razi pleonazmem i, praktycznie rzecz biorąc, wyjaśnia jedynie to, iż Polska chce respektować prawa mniejszości w stosunku do tych rzeczywistych przedstawicieli mniejszości, którzy są jej obywatelami. Wypada zwrócić uwagę, że różnica między konwencją ramową a innymi konwencjami polega na tym, że ta pierwsza ustanawia ogólne zasady, pozostawiając państwom wybór środków dla ich realizacji oraz margines swobody w doborze metod wykonania zobowiązań międzynarodowych. Normy konwencji ramowej nie mogą też być bezpośrednio stosowane w krajowym porządku prawnym i wymagają sprecyzowania w ustawodawstwie.

2 Tekst Karty został przyjęty przez Komitet Ministrów jako Konwencja Rady Europy 25 czerwca 1992 r. Kartę otwarto do podpisu 5 listopada 1992 r. Polska ratyfikowała umowę 12 lutego 2009 r., z mocą obowiązującą od 1 czerwca 2009 r. (Dz. U. 2009, Nr 137, poz. 1121). Por. także: Oświadczenie rzqdowe z dnia 22 maja 2009 r. w sprawie mocy obowiazującej Europejskiej karty języków regionalnych lub mniejszościowych, sporzqdzonej w Strasburgu dnia 5 listopada 1992 r., Dz. U. 2009, $\mathrm{Nr} 137$, poz. 1122. W karcie zdefiniowano języki regionalne lub mniejszościowe jako języki tradycyjnie używane na określonym terytorium państwa przez obywateli tego państwa tworzących grupe mniejszą liczebnie od pozostałej części ludności tego państwa, które różnią się od oficjalnego języka tego państwa. Pojęcie to nie obejmuje ani dialektów oficjalnego języka tego państwa, ani - jak już wspomniano - języków migrantów. Stwierdzono przy tym, że „terytorium, na którym używany jest język regionalny lub mniejszościowy” oznacza obszar geograficzny, na którym wspomniany język jest środkiem komunikowania się takiej liczby ludzi, która uzasadnia przyjęcie różnych środków ochronnych i wspierających przewidzianych w tejże karcie (art. 1 b). Określenie to razi dowolnością i pozostawiając ocenie państw, które ratyfikowały Kartę, to czy obszar geograficzny, na którym jakiś język regionalny lub mniejszościowy jest używany, uzasadnia już przyjęcie środków ochronnych i wspierających czy też jeszcze nie. Karta wyróżnia także ,języki nieterytorialne”, które oznaczająjęzyki używane przez obywateli danego państwa, które różnią się od języka lub języków stosowanych przez pozostałą część ludności tego państwa, chociaż są tradycyjnie używane na terytorium tego państwa, nie mogą być identyfikowane z określonym jego obszarem. 
a także do uczestnictwa w rozstrzyganiu spraw dotyczących ich tożsamości kulturowej (art. 35 ust. 2) ${ }^{3}$ (Garlicki, 2003: 4-5; Prawne, 1993: 4-5; Kallas, 1995: 63-78; Pawlak, 2001: 130-134). Warto zauważyć, że w konstytucji z natury rzeczy nie zdefiniowano pojęć „,mniejszość narodowa” i ,mniejszość etniczna”. Przyjęcie wspomnianych rozróżnień zaważyło jednak w istotny sposób nad kształtem późniejszych uregulowań. Warto pamiętać, że odróżnianie mniejszości narodowych od etnicznych nie ma w prawie międzynarodowym charakteru uniwersalnego, a oba pojęcia uznaje się za synonimy. Na gruncie konstytucji nie są to jednak pojęcia równoznaczne, o czym przekonuje przebieg prac nad jej treścią oraz to, że ustawodawca w niektórych sytuacjach operuje tylko terminem „mniejszość narodowa”4 (Gebethner, 2001: 204). Konstytucja wyraźnie wyróżnia element obiektywny - czyli faktyczne istnienie mniejszości, tak narodowe, jak etniczne od subiektywnego, który pozwala obywatelowi na swobodę wyboru, czy życzy sobie ujawnić swą przynależność, czy chce być traktowany jako członek mniejszości. Warto zauważyć, że zakres podmiotowy wolności, o jakiej mowa w art. 35 ograniczony jest tylko do obywateli polskich, pozostawiając poza polem swojego działania cudzoziemców bezpaństwowców, nawet takich, którzy przebywają w Polsce na stałe. Zakresem swoim art. 35 obejmuje jedynie te osoby, które „należą do mniejszości narodowych i etnicznych", a więc jedynie takie, które rzeczywiście powiązane są z określoną mniejszością. Warto zauważyć, że wartości, o których mowa w art. 35 ust. 1 zostały ujęte w formie negatywnej, co oznacza, że władze publiczne powinny powstrzymać się od ingerencji w określone sfery. Prawa, o jakich mowa w art. 35 ust. 2 konstytucji zostały za to określone w formie pozytywnej, co nakłada na władze publiczne obowiązek stworzenia warunków umożliwiających realizację tych praw ${ }^{5}$. Ogólnikowość sformułowania konstytucji, niezależnie od zobowiązań międzynarodowych, nakładała na Polskę obowiązek stworzenia aktu prawnego precyzującego dokładniej

3 Regulacja zawarta w art. 35 nie ma silnego oparcia w polskiej tradycji konstytucyjnej, mimo, że jak stwierdza się w literaturze „problemy ochrony praw mniejszości były przedmiotem unormowania Konstytucji marcowej, tak w wymiarze indywidualnym (art. 109 ust. 1 i art. 110), jak i grupowym (art. 109 ust. 2)", gdyż nie rozwinęło się na ich tle ani orzecznictwo, ani literatura. W okresie Polski Ludowej brak było (poza ogólnym zakazem dyskryminacji) szczególnych konstytucyjnych regulacji dotyczących sytuacji praw mniejszości. Starano się wówczas, głosząc tezę o polityczno-moralnej jedności narodu polskiego, zminimalizować możliwość kultywowania tradycji i uzewnętrzniania odrębności przez mniejszości narodowe. Problematyka mniejszości była szczegółowo analizowana przez powołaną w toku obrad Sejmu X kadencji stałą Komisję Mniejszości Narodowych i Etnicznych. Było to pierwsze tego typu ciało w pracach pierwszego Sejmu. Komisje takie istniały również w Sejmie późniejszych kadencji. Warto zauważyć, że żaden z projektów Konstytucji nie zawierał definicji pojęcia mniejszości narodowych, etnicznych i językowych.

4 Por. art. 134 ordynacji wyborczej do Sejmu i Senatu RP (Dz. U. 2001, Nr 46, poz. 499, zm. Dz. U. 2001, Nr 74, poz. 786), w którym jedynie komitety wyborcze utworzone przez wyborców zrzeszonych w zarejestrowanych organizacjach mniejszości narodowych mogą korzystać ze zwolnienia list tych komitetów od konsekwencji pięcioprocentowego progu wyborczego, uprawniającego do podziału mandatów.

${ }^{5}$ W literaturze podnosi się, że art. 35 gwarantuje mniejszościom uprawnienia: instytucjonalne (prawo do tworzenia własnych instytucji edukacyjnych, kulturalnych i służących ochronie tożsamości religijnej, a więc - prawo do własnego szkolnictwa, placówek kulturalnych i wyznaniowych, ale nie do tworzenia instytucji politycznych, administracyjnych czy gospodarczych), proceduralne (do uczestniczenia w rozstrzyganiu spraw dotyczących ich tożsamości). Wynika z tego nie tylko możliwość, a wręcz konieczność powoływania przez mniejszości organizacji. 
prawa mniejszości narodowych i etnicznych, definiujących te pojęcia i określającego obowiązki organów administracji wobec takowych mniejszości. Zauważyć należy, że traktaty dwustronne, podpisywane przez Polskę, a dotyczące problematyki mniejszościowej nie zawierają definicji mniejszości narodowych i etnicznych ${ }^{6}$ (Traktaty, 2005). W tekstach traktatów gwarantowano prawa różniące się co do swej istoty. Między innymi do: uczenia się języka ojczystego i w języku ojczystym, używania go w życiu prywatnym i publicznym, używania imion i nazwisk w brzmieniu języka ojczystego, wyznawania i praktykowania religii oraz odbywania praktyk religijnych w języku ojczystym, zakładania i utrzymywania własnych organizacji i stowarzyszeń (Janusz, Bajda, 2000b: 67; Barcz, 1996; Mikołajczyk, 1996: 87-90; Łodziński, 2003: 8-9; Łodziński, 2005: 134-137).

Uchwalona 6 stycznia 2005 r. ustawa o mniejszościach narodowych i etnicznych oraz o języku regionalnym ${ }^{7}$ stawiała sobie za cel regulację spraw związanych z zacho-

${ }^{6}$ Polska zawarła ze wszystkimi sąsiadami, a także z innymi państwami (Europy Środkowo-Wschodniej) traktaty, w których uregulowano także ochronę praw osób należących do mniejszości narodowych, deklarując jednocześnie konieczność przeciwdziałania dyskryminacji etnicznej. Traktatami takimi są: Traktat polsko-niemiecki o dobrym sqsiedztwie i przyjaznej wspótpracy, podpisany w Bonn 17 czerwca 1989 r. (Dz. U. 1992, Nr 14, poz. 56); Uktad między Rzeczypospolita Polska a Czeska i Stowackq Republika Federacyjnq o dobrym sqsiedztwie i przyjaznej wspótpracy, podpisany w Krakowie 16 października 1991 r. (Dz. U. 1992, Nr 59, poz. 296); Układ o dobrosasiedzkiej wspótpracy między Rzeczypospolita Polska a Republika Węgierska, podpisany w Krakowie 6 października 1991 r. (Dz. U. 1991, Nr 59, poz. 298); Traktat między Rzeczypospolita Polskq a Federacja Rosyjska o dobrym sqsiedztwie i przyjacielskiej wspótpracy, podpisany w Krakowie 22 maja $1991 \mathrm{r}$. (Dz. U. 1993, Nr 61, poz. 291); Traktat między Rzeczypospolita Polska a Ukrainq o dobrym sqsiedztwie i przyjaznej wspótpracy, podpisany w Warszawie 18 maja 1992 r. (Dz. U. 1993, Nr 125, poz. 573); Traktat między Rzeczypospolita Polskq a Republikq Białoruś o dobrym sqsiedztwie i przyjaznej wspótpracy, podpisany w Warszawie 23 czerwca 1992 r. (Dz. U. 1993, Nr 118, poz. 578); Traktat między Rzeczypospolita Polska a Republika Łotewska o przyjaźni i wspótpracy, podpisany w Rydze 1 lipca 1992 r. (Dz. U. 1993, Nr 114, poz. 502); Traktat między Rzeczypospolita Polska a Republikq Estońskq o wspótpracy i battyckim dobrosqsiedztwie, podpisany w Tallinie 2 lipca $1992 \mathrm{r}$. (Dz. U. 1993, Nr 121, poz. 536); Traktat między Rzeczypospolita Polskq a Republikq Litewskq o przyjaznych stosunkach i dobrosqsiedzkiej wspótpracy, podpisany w Wilnie 26 kwietnia 1994 r., Dz. U. 1995, Nr 15, poz. 71; Konkordat między Stolicq Apostolska i Rzeczypospolita Polska, podpisany w Warszawie 28 lipca 1993 r. (Dz. U. 1998, Nr 51, poz. 318). Zobowiązania dotyczące ochrony mniejszości znalazły się także w traktatach: Traktat o przyjaźni $i$ wspótpracy między Rzeczypospolita Polska a Republikq Uzbekistanu z 11 stycznia 1996 r. (Dz. U. 1996, Nr 26, poz. 115); Traktat między Rzeczpospolita Polskq a Republikq Mołdowq o przyjaźni i wspótpracy z 15 listopada 1994 r. (Dz. U. 1996, Nr 76, poz. 363).

7 Przyjęcia ustawy o mniejszościach narodowych i etnicznych domagała się od początku swojego powstania sejmowa Komisja Mniejszości Narodowych i Etnicznych. Pierwszy projekt ustawy o mniejszościach autorstwa Prof. Zdzisława Kędzi i dr Hanny Suchockiej powstał jeszcze w końcu lat osiemdziesiątych w Komitecie Obywatelskim przy Lechu Wałęsie. Nie wyszedł on jednak poza etap wstępnych prac. Następny projekt noszący nazwę ,ustawa o prawach osób przynależnych do mniejszości narodowych i etnicznych" opracowany przez Helsińską Fundację Prawa Człowieka w 1993 r. był następnie przedyskutowany na przełomie 1993 i 1994 r. przez Komisję Mniejszości Narodowych i Etnicznych i został następnie odesłany do podkomisji, która we wrześniu 1997 r. przedstawiła projekt ustawy zaakceptowany następnie przez Komisję. Prace nad ustawą podjął Sejm III kadencji, który we wrześniu 1998 r. debatował nad przedstawionym projektem i po burzliwej dyskusji postanowił odesłać projekt do komisji. Projekt ustawy o mniejszościach narodowych i etnicznych w Rzeczypospolitej Polskiej, druk sejmowy nr 616, Warszawa 16 września 1998 r. Przeciwko projektowi głoso- 
waniem i rozwojem tożsamości narodowej mniejszości narodowych i etnicznych oraz zachowaniem i rozwojem języka regionalnego, a także określenie sposobu realizacji zasady równego traktowania osób bez względu na pochodzenie etniczne ${ }^{8}$ (Biuletyn: 1-5). Prace nad tekstem ustawy trwały bardzo długo, a uchwalony tekst w istotny sposób różnił się od wstępnego projektu, jak i późniejszego projektu komisji powołanej do przygotowania ustawy (ten ostatni tekst, znany jako druk sejmowy nr 223) (Łodziński, 2004; Kallas, 1995) 9 .

Sejm IV kadencji na 88 posiedzeniu w dniu 4 listopada 2004 r. uchwalił przedstawiony projekt ustawy, wprowadzając jednak w teksie w porównaniu z projektem poważne zmiany. 5 listopada 2004 r. ustawę przekazano Prezydentowi i Marszałkowi Senatu. 6 grudnia 2004 r. Senat wniósł poprawki do projektu ustawy (Druk $n r$ 3536, 2004), które 7 grudnia 2004 r. skierowano do komisji przygotowujących projekt. Ko-

wało 115 posłów, 49 wstrzymało się od głosu. Odrzucenia projektu pragnęli posłowie PSL, KPN, ROP, oraz część klubu AWS, za skierowaniem projektu do dalszych prac opowiedzieli się posłowie UW i SLD.

8 Dz. U. 2005, Nr 17, poz. 141, zm. Dz. U. 2005, Nr 65, poz. 550. Warto zauważyć, że prace nad ustawą o mniejszościach narodowych trwały od jesieni 1993 r., kiedy to 18 listopada powołano zespół, a później, 14 stycznia 1994 r. - podkomisję do opracowania projektu ustawy o mniejszościach narodowych i etnicznych.

9 W kwietniu 1999 r. powołano specjalną komisję do opracowania ustawy o mniejszościach narodowych. Przygotowany projekt ustawy poparł rząd aczkolwiek zgłosił do jego treści wiele zastrzeżeń. Sejm III kadencji nie dokończył jednak pracy nad wspomnianą ustawą nie mogąc zdecydować się na zdefiniowanie terminu mniejszość narodowa. Sejm IV kadencji podjął na nowo prace nad ustawą o mniejszości, postanawiając skierować do pierwszego czytania projekt dyskutowany w sejmie poprzedniej kadencji. Projekt ten poparł rząd, wyrażając sprzeciw wobec propozycji utworzenia Urzędu do spraw Mniejszości Narodowych oraz podnosząc zastrzeżenia co do rozwiązań wyodrębniających szkolnictwo dla mniejszości. Dyskusja nad projektem odbyła się 15 lutego 2002 r. Posłem sprawozdawcą był poseł Eugeniusz Czykwin. Projekt poparły kluby: SLD, UP, Samoobrony, PO, PSL, przeciwni natomiast byli posłowie PiS i LPR, bojąc się kosztów wprowadzenia ustawy, rozbudowy administracji, skłócenia narodowości oraz podnosząc niedopracowanie projektu. W głosowaniu przeprowadzonym 27 lutego 2002 r. skierowano projekt do dalszych prac w komisji. W marcu 2002 r. powołano specjalną podkomisję do przygotowania projektu ustawy, która po zebraniu opinii i ekspertyz dotyczących projektu rozpoczęła we wrześniu pracę nad jego tekstem. Podkomisja na początku grudnia przygotowała nową wersję ustawy jako poselską poprawkę do istniejącego już projektu sejmowego, ale dalsze prace zostały wstrzymane do połowy 2003 r., kiedy to jesienią 2003 r. opracowano projekt zatytułowany: „ustawa o mniejszościach narodowych i etnicznych oraz języku regionalnym". Projekt ten obszerniejszy w stosunku do wcześniejszych wersji szczegółowo regulował kwestie odnoszące się do języka mniejszości oraz zasad współpracy administracji rządowej z organizacjami mniejszości. Komisja zakończyła prace nad projektem 28 kwietnia 2004 r. a sprawozdanie z jej obrad zostało przedstawione Sejmowi 25 sierpnia 2004 r. Posłem sprawozdawcą był Eugeniusz Czykwin. Zob.: Sprawozdanie komisji, Druk Sejmowy nr 3206. Drugie czytanie miało miejsce 23 września 2004 r. na 84 posiedzeniu Sejmu, na którym zgodnie z art. 47 ust. 1 skierowano ponownie projekt ustawy zawarty w druku nr 3206 do Komisji Administracji i Spraw Wewnętrznych, Komisji Edukacji, Nauki i Młodzieży oraz Komisji Mniejszości Narodowych i Etnicznych w celu rozpatrzenia wniosku o odrzucenie projektu i poprawek zgłoszonych w drugim czytaniu. Wspomniane Komisje rozpatrywały wnioski 13 i 21 października 2004 r., składając następnie dodatkowe sprawozdanie 21 października 2001 r. Druk sejmowy nr 3206-A. Dodatkowe sprawozdanie Komisji Administracji i Spraw Wewnętrznych, Komisji Edukacji, Nauki i Młodzieży oraz Komisji Mniejszości Narodowych i Etnicznych o komisyjnym projekcie ustawy o mniejszościach narodowych i etnicznych w Rzeczypospolitej Polskiej (Druk $n r$ 223). 
misje te 16 grudnia 2004 r. przyjęły część poprawek, przedstawiając sprawozdanie Sejmowi (Druk $n r$ 3584, 2004). Sejm na 95 posiedzeniu 6 stycznia 2005 r. przyjął większość poprawek. Ustawę przekazano Prezydentowi do podpisu 7 stycznia 2005 r. Podpisana została 24 stycznia 2005 r. i ogłoszona w Dzienniku Ustaw z 31 stycznia 2005 r. $^{10}$

Zamiarem ustawodawcy było także określenie w ustawie zadań i kompetencji organów administracji rządowej i jednostek samorządu terytorialnego wobec mniejszości narodowych i etnicznych. Jakkolwiek w ten sposób sformułowano cel ustawy, to jednak w uzasadnieniu projektu podkreślono, że ma ona odnosić się do mniejszości objętych polityką państwa polskiego, wykluczając inne zbiorowości tworzone przez cudzoziemców lub inne etnograficzne grupy „należące do narodu polskiego”.

Projekt pierwotny ustawy zawierał odniesienia do niemal wszystkich zasad zawartych w Konwencji Ramowej Rady Europy o ochronie mniejszości narodowych. Obejmował on zatem katalog praw przysługujących mniejszościom narodowym, zakaz dyskryminacji z powodów narodowych lub etnicznych oraz asymilacji (Sobczak, $2008)^{11}$.

10 Dz. U. 2005, Nr 17 poz. 141. Ustawa była trzykrotnie nowelizowana. Po raz pierwszy już ustawą z dnia 3 marca 2005 r. o zmianie ustawy o zmianie imion i nazwisk oraz o zmianie niektórych innych ustaw (Dz. U. 2005, Nr 62, poz. 550), której art. 44 uchylił treść art. 33 ustawy o mniejszościach narodowych, etnicznych i języku regionalnym, którym zmieniono treść ustawy z 15 listopada 1956 r. o zmianie imion i nazwisk (Dz. U. 1963, Nr 59, poz. 328 z późn. zm.), dodając w art. 2 tejże ustawy ust. 3 , pozwalający na powrócenie do nazwisk lub imion, których zmiana nastąiła z powodu ich niepolskiego brzemienia w wyniku decyzji administracyjnej podjętej bez wniosku zainteresowanego. Kolejną zmianę przyniosła ustawa z 23 stycznia 2009 r. o wojewodzie i administracji rządowej w województwie, której art. 77 zmienił treść art. 22 ust. 3 ustawy o mniejszościach narodowych i etnicznych oraz języku regionalnym, nadając mu treść: ,,wojewoda może ustanowić pełnomocnika do spraw mniejszości narodowych i etnicznych. Przepisu art. 18 ust. 1 ustawy z dnia 23 stycznia 2009 r. o wojewodzie i administracji rządowej w województwie (Dz. U. Nr 31, poz. 206) nie stosuje się". Kolejna zmiana wprowadzona przez art. 66 ustawy z dnia 27 sierpnia 2009 r. przepisy wprowadzające ustawę o finansach publicznych (Dz. U. 2009, Nr 157, poz. 1241 z późn. zm.) odnosił się do treści art. 18 ustawy z dnia 6 stycznia 2005 r. W treści tego przepisu po ust. 3 dodano ust. 3 a w brzmieniu: „3a. łączna kwota dotacji przyznanych w kolejnych latach na dofinansowanie inwestycji, o których mowa w ust. 2 pkt 2, niepochodzących z budżetu Unii Europejskiej, nie może być wyższa niż 90\% planowanej wartości kosztorysowej inwestycji.”, ust. 5 otrzymał brzmienie: ,5. Dotacje podmiotowe, o których mowa w ust. 2, mogą otrzymywać organizacje mniejszości lub mające istotne znaczenie dla kultury mniejszości instytucje kulturalne. Przepis art. 122 ust. 4 ustawy z 27 sierpnia 2009 r. o finansach publicznych (Dz. U. 2009, Nr 157, poz. 1240) stosuje się odpowiednio".

11 Uznając zasadę równości obywateli, nie wykluczał możliwości prowadzenia wobec mniejszości narodowych polityki preferencyjnej, zmierzającej do wyrównania szans. Na terenach zamieszkałych tradycyjnie lub w znacznej liczbie przez osoby należące do mniejszości narodowych projekt przewidywał możliwość traktowania języków mniejszości jako języków pomocniczych, uwzględnia także możliwość określania w językach mniejszości nazw miejscowości organów władz oraz ulic. Gwarantowała także prawo urzędowego zapisywania imion i nazwisk zgodnie z zasadami języka ojczystego. Odrębny rozdział został poświęcony oświacie i kulturze mniejszości narodowych, regulując naukę języka ojczystego i w tym języku oraz zasady odnoszące się do finansowania imprez kulturalnych mniejszości narodowych, a także zasady publicznej radiofonii i telewizji. Projekt przewidywał powołanie urzędu do spraw mniejszości narodowych, na którego czele stanąłby prezes odpowiedzialny za realizację polityki państwa wobec mniejszości narodowych. Tekst projektu datowany 11 stycznia 2002 r. (MNE - 020-01/02). Por.: Druk Sejmowy nr 223, 11.01.2002. 
W uzasadnieniu projektu zwrócono uwagę na kwestie terminologiczne, wywodząc, że tytuł ustawy „O mniejszościach narodowych i etnicznych” wynika z nazewnictwa stosowanego w Europie - różnego od przyjętego w systemie prawnym ONZ, w którym mowa o „prawach osób należących do mniejszości”. Zauważono, że takie ujęcie praw odnoszone jest wyłącznie do praw indywidualnych, które mogą być realizowane także wespół z innymi członkami danej grupy (Uzasadnienie, 2002). Treść ustawy postawiła przed ustawodawcą konieczność zdefiniowania pojęcia „mniejszości narodowej, i „,mniejszości etnicznej”, a także „języka regionalnego" ${ }^{12}$ (Postanowienia Sadu Naj-

12 Zdefiniowanie pojęcia „mniejszość narodowa” nastręczało ogromne trudności. W projekcie art. 2 ustawy sformułowano definicję opisową mniejszości narodowej lub etnicznej stwierdzając: „Przez mniejszość narodową lub etniczną, zwaną dalej »mniejszością" rozumie się grupę obywateli Rzeczypospolitej Polskiej o odrębnym pochodzeniu tradycyjnie zamieszkałą na terytorium Rzeczypospolitej Polskiej, pozostającą w mniejszości w stosunku do reszty obywateli charakteryzującą się dążeniem do zachowania swojego języka, obyczajów, tradycji, kultury, religii lub świadomości narodowej lub etnicznej”. W toku prac nad tekstem ustawy zauważono jednak, że tego rodzaju ujęcie jest wysoce niezadowalające oraz, że sama deklaracja członków zbiorowości jest niewystarczająca, aby mogła się ona stać mniejszością narodową bądź etniczną. Zauważono, że warunkiem zaistnienia takiej grupy, oprócz deklaracji jej członków, jest jednoczesne uznanie odrębności przez inne zbiorowości. Na takim stanowisku stanął Sąd Najwyższy, uznając, iż niedopuszczalna jest rejestracja stowarzyszenia „Związek Ludności Narodowości Śląskiej”, podkreśliwszy, że mniejszość narodowa może istnieć tylko jako ukształtowana w procesie historycznym i społecznie akceptowana grupa narodowa. Europejski Trybunał Praw Człowieka, rozpoznając skargę na orzeczenie Sądu Najwyższego nie wdawał się wprawdzie w problematykę definicji mniejszości narodowych i etnicznych, stwierdzając jedynie, że taką definicję trudno by było zdefiniować, gdyż nie było ono definiowane w żadnym dokumencie prawa międzynarodowego, także w konwencji ramowej Rady Europy. Nie dopatrzył się on naruszenia przepisów prawa poprzez odmowę rejestracji. W efekcie odmowę rejestracji stowarzyszenia uznano za konieczną w demokratycznym społeczeństwie w świetle art. 11 ust. 2, uznając, że nie doszło do naruszenia Europejskiej Konwencji Praw Człowieka i Podstawowych Wolności. Zob.: Gorzelik i inni przeciwko Polsce - orzeczenie z 17 lutego 2004 r., skarga nr 44158/98. Akcentowano, że samoidentyfikacja odbywa się zawsze w odniesieniu do innych grup oraz, że w takim kontekście może być postrzegana odrębność grupy. Innymi słowy, subiektywna deklaracja przynależności do określonej grupy narodowościowej zakłada uprzednią akceptację społeczną istnienia takiej grupy. Powołując się na Komentarz do Postanowień Konwencji Ramowej o Mniejszościach Narodowych z 1995 r., którą Polska podpisała w kwietniu 2000 r., stwierdzano, że subiektywny wybór narodu przez człowieka jest zawsze nieodłącznie związany z obiektywnymi kryteriami istotnymi dla tożsamości narodowej. Podkreślano także, że w definicji opisowej należałoby umieścić dodatkowy zapis odnoszący się do wyznacznika historycznej obecności na danym terytorium, gdyż pojęcie „tradycyjnie zamieszkała na terytorium Rzeczypospolitej Polskiej” jest wysoce nieostre. Proponowano rozważenie możliwości odejścia od definicji opisowej i skonkretyzowanie pojęcia „mniejszość narodowa” przez wyliczenie grup uważanych za mniejszości. Podnoszono przy tym konieczność uzgodnienia elementu trwałego osadnictwa, z uwagi na pojawianie się wspólnot o czysto emigracyjnym rodowodzie (tzw. nowych mniejszości), które w przyszłości mogą domagać się statusu mniejszości narodowej. W uzasadnieniu tekstu podkreślono, że ustawa przyjmuje podmiotowy zakres jej obowiązywania, ograniczając go do osób o obywatelstwie polskim oraz należących do mniejszości ,tradycyjnie zamieszkałych na terytorium państwa polskiego”, tj. takich, które charakteryzują się „długoletnim (wielowiekowym) zamieszkiwaniem wśród społeczeństwa polskiego”. Twórcy ustawy nie zauważyli przy tym, iż pojęcie „,wielowiekowy” nie jest synonimem „długoletniego”. Podkreślono także w treści uzasadnienia, że zaakcentowanie w art. 2 projektu, iż mniejszość narodowa lub etniczna to grupa obywateli „o odrębnym pochodzeniu”, a nie „odrębna narodowość”. Wynikało to z faktu, że definiowany jest podmiot o charakterze zbiorowym, tj. mniejszość, a nie o charakterze indywidualnym - a więc osoby należące do mniejszości. Jak wskazuje na to treść uzasadnienia, zdaniem twórców ustawy tego typu definicja 
wyższego, 1999; Nowy Europejski, 2005: 1159-1168; Wójtowicz, 2002: 5). W pierwotnym tekście nie rozróżniano pojęć „mniejszość narodowa” i „mniejszość etniczna” podejmując próbę określenia tych terminów dopiero w uzasadnieniu projektu.

Przeprowadzony w 2002 r. Spis Powszechny potwierdził istnienie znacznych grup mniejszości: białoruskiej, litewskiej, łemkowskiej, romskiej, rosyjskiej, słowackiej, ukraińskiej i żydowskiej. Przynależność do narodowości kaszubskiej zadeklarowały 5053 osoby legitymujące się w zasadzie jedynie obywatelstwem polskim, a narodowość śląską 172682 osoby, także w pierwszym rzędzie będących obywatelami polskimi (Łodziński, 2006: 171-205; Gudaszewski, 2006: 89-114; Babiński, 2004: 147; Ludność, 2008) ${ }^{13}$.

W uzasadnieniu projektu zaakcentowano konieczność zapewnienia przedstawicielom mniejszości narodowych możliwości posługiwania się językiem ojczystym w życiu publicznym w relacji z organami administracji, wskazując że wynika to zarówno z art. 10 ust. 2 i 3 Konwencji ramowej jak i pkt 34 Dokumentu Spotkania Kopenhaskiego Konferencji w sprawie ludzkiego wymiaru KBWE z 29 czerwca 1990 r. (Sobczak, 2008: 9-43) $)^{14}$.

wskazuje, że jest ona skierowana do mniejszości o innym niż polskie pochodzeniu, przy czym nie stwarza to jednocześnie praw w wymiarze grupowym. W uzasadnieniu projektu wskazano, że pojęcie mniejszości narodowej powinno być odnoszone do mniejszości utożsamiającej się z narodami zorganizowanymi we własnym państwie, a więc do: białoruskiej, czeskiej, niemieckiej, rosyjskiej, ormiańskiej, słowackiej, ukraińskiej, żydowskiej. Natomiast mniejszość etniczną twórcy projektu ustawy chcieli wiązać z tzw. „mniejszościami bezpaństwowymi”, zaliczając do niej karaimską, romską (cygańską), tatarską, łemkowską (jak zaznaczono w uzasadnieniu, w odniesieniu do tej części społeczności łemkowskiej, która uznaje się za odrębną od narodu ukraińskiego). Jest rzeczą ciekawą, że w projekcie nie wspomniano ani słowem o mniejszościach: greckiej i węgierskiej. Przedstawiciele drugiej z nich to grupa niewielka liczbowo, dość rozproszona na całym obszarze państwa, przy czym część z nich zamieszkuje tereny Polski od dawna, część zaś to uchodźcy pozostali w Polsce po $1956 \mathrm{r}$. i osoby pozostające w tzw. „mieszanych” związkach małżeńskich. Ludność grecka, jakkolwiek osiedlała się na terytorium Polski od dawna, to jednak większość z nich to osoby, które znalazły się w Polsce, jako emigranci polityczni po II wojnie światowej.

${ }_{13}$ Spis przyniósł też informację o istnieniu w Polsce narodowości: wietnamskiej, (ok. 1,8 tys.), francuskiej (1,6 tys.), w ramach której wyłącznie polskie obywatelstwo deklarowało 42,7\%, amerykańskiej (1,5 tys.), greckiej (1,4 tys.), włoskiej (1,4 tys.), bułgarskiej ( 1,1 tys.), żydowskiej $(1,1$ tys.), ormiańskiej ( 1,1 tys.), czeskiej ( 0,8 tys.), angielskiej ( 0,8 tys.), arabskiej (0,5 tys.), kanadyjskiej ( 0,5 tys.), holenderskiej ( 0,5 tys.), tatarskiej ( 0,5 tys. $)$, wegierskiej ( 0,5 tys. $)$, serbskiej $(0,4$ tys. $)$, szwedzkiej ( 0,3 tys.), austriackiej ( 0,3 tys.), chorwackiej ( 0,3 tys.), rumuńskiej ( 0,3 tys.), syryjskiej (0,3 tys.), pakistańskiej ( 0,2 tys.), hinduskiej ( 0,2 tys.), belgijskiej ( 0,2 tys.), chińskiej $(0,2$ tys.), hiszpańskiej ( 0,2 tys.), algierskiej ( 0,2 tys.), australijskiej ( 0,2 tys.), macedońskiej ( 0,2 tys.), palestyńskiej ( 0,2 tys.), irańskiej $(0,1$ tys.), japońskiej $(0,1$ tys.), libańskiej $(0,1$ tys.), totewskiej $(0,1$ tys.), marokańskiej ( 0,1 tys.), mongolskiej ( 0,1 tys.), norweskiej $(0,1$ tys.), afgańskiej $(0,1$ tys.), tunezyjskiej ( 0,1 tys.), karaimskiej ( 0,05 tys.). Narodowość tatarską, karaimską zadeklarowały nieliczne osoby, aczkolwiek wpływ na to miały bardzo różne czynniki, a wśród nich obawa przed konsekwencjami ujawnienia swojej identyfikacji etnicznej, postawa rachmistrzów i złożona świadomość narodowa, a także zmiana sposobu definiowania swojej przynależności grupowej oraz wystapienie zjawiska tzw. „etniczności symbolicznej”. Zob. także wyniki Narodowego Spisu Powszechnego Ludności i Mieszkań 2002 w zakresie deklarowanej narodowości oraz języka używanego w domu.

14 Podkreślono także, że przepisy traktatów dwustronnych, jakie Polska zawarła z sąsiadami gwarantują osobom należącym do mniejszości prawo posługiwania się językiem ojczystym w życiu prywatnym i publicznie (sic.!) - jak to sformułowano w traktatach z Niemcami i Litwą, bądź w życiu prywatnym i publicznym - jak stanowią traktaty z Czechami Słowacją i Białorusią. Dowodzi to, iż 
Opiniujący projekt eksperci podnieśli wątpliwości dotyczące techniki prawodawczej w szczególności w zakresie formułowania upoważnień ustawowych do wydania rozporządzeń wykonawczych. Podniesiono także zastrzeżenia dotyczące potrzeby utworzenia Urzędu do Spraw Mniejszości Narodowych, brak określenia kto sprawuje nadzór nad tym Urzędem. Wskazano także, iż projekt powodować może znaczne obciążenia finansowe Skarbu Państwa. Wytknięto także liczne nieprecyzyjności w treści przepisów $^{15}$. Podnoszono także, że prawa mniejszości narodowych winny być regulowane zgodnie z zasadą wzajemności, zauważając że próby wprowadzenia języka pomocniczego społeczeństwo polskie uznaje za szkodliwe godzące w polski interes narodowy i zagrażający integralności terytorialnej i suwerenności państwa, szczególnie wtedy gdy w języku tym miałyby być określone nazwy miejscowości ulic i urzędów ${ }^{16}$.

prawidłowym jest przyjęte $\mathrm{w}$ treści art. 10 projektu rozwiązanie pozwalające osobom należącym do mniejszości używać na terenie gminy, którą zamieszkują swojego języka ojczystego w kontaktach z organami władzy publicznej jako języka pomocniczego. Przez język pomocniczy w projekcie rozumiano język ojczysty określonej mniejszości narodowej używany, stosownie do przepisów ustawy obok języka urzędowego. W uzasadnieniu podkreślono, że art. 8 i 10 czyni zadość regulacjom traktatowym i wypełnia postanowienia art. 27 zdania 2 Konstytucji RP. Zauważono przy tym, że słuszne jest rozwiązanie, aby na terenie gminy ,zamieszkałej tradycyjnie” lub w znacznej ilości przez osoby należące do mniejszości nazwy miejscowości, organów władzy publicznej oraz ulic mogły być określane także w językach ojczystych tych mniejszości. Zaakcentowano, że projekt udziela Radzie Ministrów delegacji ustawowej pozwalającej na określenie w drodze rozporządzenia wykazu gmin, w których można używać języka pomocniczego podkreślając, że niecelowe jest określanie w formie procentowej lub liczbowej wielkości ludności należącej do mniejszości, zamieszkałej w danej gminie, jako podstawy do wprowadzenia języka pomocniczego bądź uznanie za taką podstawę wyników referendum gminnego. W projekcie proponowano także rozwiązania odnoszące się do zasad prowadzenia placówek oświatowych i kulturalnych dla mniejszości narodowych, widząc konieczność powołania centralnego organu administracji rządowej w postaci Prezesa Urzędu do Spraw Mniejszości Narodowych, do którego kompetencji miałaby należeć realizacja i koordynowanie polityki państwa wobec mniejszości. Zwracano przy tym uwagę, iż wprowadzenie projektu w życie jako ustawy pociągnie za sobą dodatkowe koszty z budżetu państwa związane z powołaniem i funkcjonowaniem Urzędu do Spraw Mniejszości Narodowych oraz obciążeniami dotyczącymi tłumaczeń, a także ceną dodatkowych tablic $\mathrm{z}$ nazwami miejscowości i urzędów.

${ }_{15}$ Patrz: Opinia Eugeniusza Tomaszczuka w sprawie komisyjnego projektu ustawy o mniejszościach narodowych $i$ etnicznych w Rzeczpospolitej Polskiej z 26 czerwca 2002 r.

16 Patrz: Opinia z 8 lipca 2002 r. dr Bernadetty Wójtowicz o projekcie ustawy o mniejszościach narodowych $i$ etnicznych $w$ Rzeczpospolitej Polskiej z 26 czerwca 2002 r.; Opinia z 26 czerwca 2002 r. prof. dr hab. Grzegorza Janusza dotyczqca komisyjnego projektu ustawy o mniejszościach narodowych i etnicznych Rzeczpospolitej Polskiej. W opiniach wytknięto uproszczenia w definiowaniu pojęcia mniejszość narodowa zauważając, iż rodzi to także implikacje polityczne przy okazji wyborów wywołane chęcią ominięcia 5\% progu wyborczego. Zwrócono także uwagę, iż projekt powtarza uregulowania zawarte w Konstytucji i w niektórych innych ustawach. Zauważano także, iż niebezpiecznym zjawiskiem jest przyznawanie mniejszościom narodowym w Polsce większych praw od tych, jakie posiadają Polacy w państwach, z których wywodzą się członkowie tych mniejszości. Podnoszono także, iż próba zbudowania odrębnego systemu oświaty doprowadzić musi do izolacji szkolnictwa mniejszościowego. Akcentowano także, iż roszczenie sobie pretensji do nadmiernej ochrony mniejszości na terenie obcego państwa może oznaczać szukanie sposobu ingerencji w jego wewnętrzne sprawy, a nadanie indywidualnych praw dla grup narodowościowych dzielić będzie już tylko cienka granica, za którą znajduje się prawo do samostanowienia. Por.: Opinia z 30 czerwca $2002 \mathrm{r}$. dr Roberta Paruzela dotyczqca komisyjnego projektu ustawy o mniejszościach narodowych i etnicznych. Zauważając, że projekt ustawy był przygotowywany niezwykle długo, podnoszono, że mimo iż budzi on kontrowersje powinien być jednak przyjęty, gdyż ułatwi realizację postanowień konwencji ramo- 
Najbardziej instruktywna z przedstawionych opinii wydaje się być opinia prof. Cezarego Mika (Opinia, 2002) ${ }^{17}$.

Ostatecznie przyjęty tekst ustawy różni się poważnie od projektu, a długi okres dyskusji nad treścią poszczególnych uregulowań wyszedł w ostatecznym rozrachunku na dobre. W ustawie zdecydowano się ostatecznie na odejście od opisowej definicji zarówno „mniejszości narodowej”, jak i „etnicznej” - wskazując, że mniejszością narodowa, w rozumieniu ustawy, jest grupa obywateli polskich, która spełnia łącznie

wej, podkreślając że ustawy dotyczące mniejszości narodowych ma wiele państw europejskich w tym m.in. Białoruś, Czechy, Litwa, Słowenia, Węgry, Ukraina, a także kraje związkowe Niemiec (Saksonia i Brandenburgia w odniesieniu do Serbów). Patrz: Opinia z 17 lutego 2004 r. Stawomira Łodzińskiego o projekcie ustawy o mniejszościach narodowych.

17 Podkreślono w niej, iż projekt ustawy definiując mniejszość narodową i etniczną przyjmuje rozwiązania niemieckie oparte na restryktywnym pojmowaniu mniejszości, jako grupy o odrębnym pochodzeniu legitymującej się tradycją zamieszkania w granicach państwa oraz obywatelstwem państwa. Podkreślono jednak, że w prawie międzynarodowym ochrona mniejszości niekoniecznie musi ograniczać się do obywateli, a może obejmować także cudzoziemców. Zwrócono uwagę na konieczność zawarcia w treści ustawy regulacji, która pozwalałaby osobom należącym do mniejszości korzystać z przynależnych praw wspólnie z innymi, co gwarantuje art. 3 konwencji ramowej. Zaakcentowano, iż w projekcie brak zasad poszanowania przez osoby należące do mniejszości prawa polskiego oraz powstrzymania się od działań sprzecznych z postanowieniami prawa międzynarodowego, co także gwarantuje w art. 20 i 21 konwencja ramowa. Zauważono wreszcie, że katalog praw osób należących do mniejszości nie jest wyczerpujący i nie bardzo wiadomo czemu miałby on służyć. Ponadto opiniujący podkreślił, że ustawodawca nakazuje organom władzy publicznej wspierać działania mające na celu podtrzymywanie i rozwijanie tożsamości narodowej lub etnicznej osób należących do mniejszości, podczas gdy konwencja ramowa w art. 5 § 1 zobowiązuje państwo do stworzenia warunków koniecznych do utrzymywania i rozwijania kultury oraz zachowania zasadniczych elementów tożsamości. Podniesiono wreszcie, że nie jest jasne, na jakiej zasadzie miałaby się odbywać nauka języka ojczystego osoby należącej do mniejszości w sytuacji, gdy nie musi ona złożyć oświadczenia o przynależności do niej, co pozwalałoby na przykład Polakom na domaganie się, aby mogli się uczyć po niemiecku. Zakwestionowano także rozwiązanie polegające na wskazaniu publicznej radiofonii i telewizji jako jednego z zadań promowania wiedzy o historii życiu i kulturze mniejszości narodowych zamieszkałych w Polsce oraz produkcji i emisji programów w językach ojczystych proponując, aby tego typu zapis znowelizował ustawę o radiofonii i telewizji. W końcowej części Prof. C. Mik wypowiedział się przeciwko utworzeniu urzędu do spraw narodowych, zauważając że projektowana ustawa przewiduje koszty niezmiernie trudne do oszacowania. Por.: Opinia z 1 lipca 2002 r. prof. C. Mika w sprawie projektu ustawy o mniejszościach narodowych i etnicznych w Rzeczypospolitej Polskiej (druk nr 223); Projekt opinii z 18 stycznia 2002 roku Zespolu Integracji Europejskiej zostat uznany za niesprzeczny z prawem Unii Europejskiej. We wspomnianej opinii podkreślono, że kwestie związane z pochodzeniem etnicznym regulowane są dyrektywą Rady nr 2000/43/WE z 29 czerwca 2000 r. w sprawie wdrożenia zasady równego traktowania osób bez rozróżnienia rasy lub pochodzenia etnicznego. OJ L 180. Pewną wskazówką może być także treść Opinii Komitetu Regionów w sprawie „Promocji i ochrony języków regionalnych i mniejszości”, OJ C 357, choć należy pamiętać, że nie jest to akt prawny. Zauważono w opinii, że zgodnie z orzeczeniem Trybunału Sprawiedliwości (sprawa C-274/96 z 24 listopada 1998 r. w sprawie karnej przeciwko Horst Otto Bickel i Urlich Franz) prawo przyznane przez ustawodawstwo krajowe prowadzenia sprawy karnej w języku innym niż język podstawowy danego państwa wynika z Traktatu WE i musi respektować jego art. 6 (obecny art. 12). Ponadto Trybunał wypowiedział pogląd, że art. 6 (12) TWE jest sprzeczny z legislacją krajowa, jeżeli przyznaje obywatelom określonego języka innego niż język podstawowy danego kraju, którzy posiadają miejsce zamieszkania na terenie zamieszkałym przez określoną społeczność, prawo prowadzenia sprawy karnej w ich języku, bez przyznania tego samego prawa obywatelom innych państw członkowskich, posługujących się tym samym językiem, jeżeli przebywają na tym terytorium. 
następujące warunki, a mianowicie: jest mniej liczebna od pozostałej części ludności Rzeczypospolitej; w sposób istotny odróżnia się od pozostałych obywateli językiem, kulturą lub tradycją; dąży do zachowania swojego języka, kultury lub tradycji; ma świadomość własnej historycznej wspólnoty narodowej jest ukierunkowana na jej wyrażanie i ochronę; jej przodkowie zamieszkiwali obecne terytorium Rzeczypospolitej od co najmniej 100 lat; utożsamia się z narodem zorganizowanym we własnym państwie. Za mniejszości narodowe ustawodawca uznał jedynie mniejszości: białoruską, czeską, litewska, niemiecką, ormiańską, rosyjską, słowacką, ukraińską, żydowską. Definiując mniejszość etniczną ustawodawca wskazał w gruncie rzeczy te same warunki, które określił w odniesieniu do mniejszości narodowej, ale z dwiema zmianami, a mianowicie: mniejszość ta ma mieć świadomość własnej historycznej wspólnoty etnicznej, a nie narodowej, co wymagana w odniesieniu do mniejszości etnicznej oraz nie utożsamia się z narodem zorganizowanym we własnym państwie (mniejszości narodowe miały się utożsamiać z narodem zorganizowanym we własnym państwie). Za mniejszości etniczne uznano: karaimską, łemkowską, romską i tatarską. W ustawie stwierdzono, że każda osoba należąca do mniejszości ma prawo do swobodnej decyzji o traktowaniu jej jako osoby należącej, bądź nie należącej do mniejszości, a wybór taki lub korzystanie ze związanych z tym wyborem praw nie pociąga za sobąjakichkolwiek negatywnych skutków. Podkreślono także, że nikt nie może być obowiązany inaczej niż na podstawie ustawy do ujawnienia informacji o własnej przynależności do mniejszości lub ujawnienia swojego pochodzenia, języka mniejszości lub religii. Nikt też nie może być zobowiązany do udowodnienia własnej przynależności do mniejszości. Bardzo ważne jest także stwierdzenie, że osoby należące do mniejszości mogą korzystać z praw i wolności wynikających z ustawy indywidualnie bądź też wspólnie z innymi członkami swojej mniejszości (art. 4). W ustawie wyraźnie zabroniono stosowania środków mających na celu asymilowanie osób należących do mniejszości wbrew woli takich osób oraz stosowania środków mających na celu zmianę proporcji narodowościowych lub etnicznych na obszarach zamieszkałych przez mniejszość. Zabraniając dyskryminacji wynikających z przynależności do mniejszości, zobowiązano organy władzy publicznej do podejmowania odpowiednich środków w celu popierania pełnej rzeczywistej równości w sferze życia ekonomicznego, społecznego, politycznego i kulturalnego pomiędzy osobami należącymi do mniejszości a tymi, które należą do większości oraz ochrony osób, które są obiektem dyskryminacji wrogości bądź przemocy będących skutkiem ich przynależności do mniejszości. Organom władzy publicznej nakazano także umacnianie dialogu międzykulturowego.

Ustawodawca nie znalazł podstaw do uznania za mniejszość etniczną lub narodową ludności śląskiej bądź kaszubskiej. Stwierdził jednak, że język kaszubski jest w rozumieniu ustawy, zgodnie z Europejska Karta Języków Regionalnych lub Mniejszościowych - językiem regionalnym. Podkreślił, że językiem regionalnym jest język, który jest tradycyjnie używany na terytorium danego państwa przez jego obywateli, którzy stanowią grupę liczebnie mniejszą od reszty ludności tego państwa, a ponadto różni się od oficjalnego języka tego państwa, a nie jest ani dialektem tego języka, ani językiem migrantów (art. 19).

Osoby należące do mniejszości narodowych i etnicznych oraz w myśl art. 19 ust. 2 zdanie 2 ustawy mają - jak stwierdzono w ustawie - prawo do używania i pisowni swo- 
ich imion i nazwisk zgodnie z zasadami pisowni języka mniejszości w szczególności do rejestracji w aktach stanu cywilnego i w dokumentach tożsamości. Podkreślono, że imiona i nazwiska osób należących do mniejszości (a także używających języka regionalnego - z mocy art. 9 ust. 2 zdanie 2) zapisane w alfabecie innym niż łaciński podlegają transliteracji. Jednocześnie udzielono ministrowi właściwemu do spraw administracji publicznej, aby w porozumieniu z ministrem właściwym do spraw wyznań religijnych oraz mniejszości narodowych i etnicznych określił w drodze rozporządzenia sposób takowej transliteracji (Rozporzadzenie, 2005a). Osobom należącym do mniejszości oraz tym, które używają języka regionalnego przyznano prawo swobodnego posługiwania się tym językiem w życiu prywatnym i publicznie, rozpowszechniania i wymiany informacji w tym języku zamieszczania w nim informacji o charakterze prywatnym oraz do nauki języka mniejszości lub w języku mniejszości. Przed organami gminy język mniejszości oraz język regionalny może być - jak stwierdzono - używany jako język pomocniczy, z tym że ograniczono to tylko i wyłącznie do gmin, w których liczba mieszkańców, należących do mniejszości, której język ma być używany jako pomocniczy, lub osób używających języka regionalnego, jest nie mniejsza niż 20\% ogólnej liczby mieszkańców gminy i które zostały wpisane do Urzędowego Rejestru Gmin, w których możliwe jest używanie języka pomocniczego. Możliwość używania języka pomocniczego oznacza, że osoby należące do mniejszości mają prawo do zwracania się do organów gminy w języku pomocniczym w formie pisemnej lub ustnej oraz do uzyskiwania jednak na wyraźny wniosek odpowiedzi w języku pomocniczym w formie pisemnej lub ustnej. Wyraźnie podkreślono, że możliwe jest wniesienie podania w języku pomocniczym i fakt ten nie może stanowić podstawy pozostawienia takowego podania bez rozpoznania. Zawarowano jednak, że procedura odwoławcza odbywać się będzie wyłącznie w języku urzędowym, a nikt nie może się uchylić od wykonania zgodnego z prawem polecenia lub orzeczenia wydanego w języku urzędowym, jeżeli okoliczności wymagają niezwłocznego jego wykonania. Ewentualne wątpliwości między treścią dokumentu sporządzonego w języku urzędowym a pomocniczym mogą być rozstrzygane jedynie na podstawie dokumentu sporządzonego w języku urzędowym, czyli polskim. $Z$ treści art. 9 ustawy wynika dość wyraźnie, że przyznanie językowi statusu języka pomocniczego oznacza dokonywanie w tym języku określonych przez ustawę czynności i to jedynie przed organami gmin. Interpretacja rozstrzygająca wydaje się być niedopuszczalna (Skóra, 2005: 411 i n.).

W myśl ustawy, wpisu do Urzędowego Rejestru dokonuje prowadzący ten rejestr minister ,właściwy do spraw wyznań religijnych oraz mniejszości narodowych i etnicznych", na podstawie wniosku rady gminy. Wniosek ten powinien zawierać dane urzędowe dotyczące liczby mieszkańców gminy, w tym liczby mieszkańców należących do mniejszości, której język ma być używany jako język pomocniczy, oraz uchwałę rady gminy o wyrażeniu zgody na wprowadzenie języka pomocniczego wraz ze wskazaniem języka mniejszości, który ma być językiem pomocniczym. Przed dokonaniem wpisu do Urzędowego Rejestru wspomniany minister weryfikuje wniosek. Może odmówić dokonania wpisu do Urzędowego Rejestru, jeżeli wniosek nie spełnia wymogów określonych w ustawie. Ma natomiast obowiązek odmowy dokonania wpisu, jeżeli liczba mieszkańców gminy należących do mniejszości, której język ma być używany jako język pomocniczy, jest mniejsza niż $20 \%$ ogólnej liczby mieszkańców 
tej gminy. Na odmowę dokonania wpisu do Urzędowego Rejestru radzie gminy przysługuje - w myśl ustawy - skarga do sądu administracyjnego. Na wniosek rady gminy minister właściwy do spraw wyznań religijnych oraz mniejszości narodowych i etnicznych wykreśla gminę z Urzędowego Rejestru. Minister właściwy do spraw wyznań religijnych oraz mniejszości narodowych i etnicznych określi, w porozumieniu z ministrem właściwym do spraw administracji publicznej, w drodze rozporządzenia, sposób prowadzenia Urzędowego Rejestru oraz wzór wniosku o wpis do rejestru (Rozporzqdzenie, 2005b).

W myśl ustawy w gminie wpisanej do Urzędowego Rejestru pracownikom zatrudnionym w urzędzie gminy, $w$ jednostkach pomocniczych gminy oraz w gminnych jednostkach i zakładach budżetowych może być przyznany dodatek z tytułu znajomości języka pomocniczego obowiązującego na terenie tej gminy. Zasady przyznawania dodatku oraz jego wysokość określą przepisy dotyczące zasad wynagradzania pracowników samorządowych.

Znajomość języka pomocniczego potwierdza dyplom, zaświadczenie lub certyfikat. Minister właściwy do spraw wyznań religijnych oraz mniejszości narodowych i etnicznych został zobowiązany ustawą do określenia, w porozumieniu z ministrem właściwym do spraw oświaty i wychowania, w drodze rozporządzenia, wykazu dyplomów, zaświadczeń lub certyfikatów potwierdzających znajomość języka pomocniczego (Rozporzqdzenie, 2005c).

W ustawie stwierdzono, że dodatkowe tradycyjne nazwy w języku mniejszości mogą być używane obok ustalonych w języku polskim, na podstawie odrębnych przepisów: urzędowych nazw miejscowości i obiektów fizjograficznych oraz nazw ulic. Dodatkowe nazwy mogą być przy tym używane jedynie na obszarze gmin wpisanych do prowadzonego przez ministra „właściwego do spraw wyznań religijnych oraz mniejszości narodowych i etnicznych" Rejestru gmin, na których obszarze używane są nazwy w języku mniejszości. Nie mogą one jednak absolutnie nawiązywać do nazw z okresu 1933-1945, nadanych przez władze Trzeciej Rzeszy Niemieckiej lub Związku Socjalistycznych Republik Radzieckich. Wolno je wprowadzić na terenie całej gminy lub w poszczególnych miejscowościach. Nie mogą być jednak stosowane samodzielnie i muszą zostać umieszczone po nazwie w języku polskim. Ustalenie dodatkowej nazwy w języku mniejszości następuje zgodnie z zasadami pisowni tego języka.

Dodatkowa nazwa miejscowości lub obiektu fizjograficznego w języku mniejszości może być ustalona na wniosek rady gminy, jeżeli: liczba mieszkańców gminy należących do mniejszości jest nie mniejsza niż 20\% ogólnej liczby mieszkańców tej gminy lub, w przypadku miejscowości zamieszkanej, gdy za ustaleniem dodatkowej nazwy miejscowości w języku mniejszości opowiedziała się w konsultacjach, przeprowadzonych w trybie określonym w art. 5a ust. 2 ustawy z 8 marca 1990 r. o samorządzie gminnym $^{18}$, ponad połowa mieszkańców tej miejscowości biorących udział w konsultacjach. Ponadto wniosek rady gminy musi uzyskać pozytywną opinię Komisji Nazw Miejscowości i Obiektów Fizjograficznych, utworzonej na podstawie ustawy z 29 sierpnia 2003 r. o urzędowych nazwach miejscowości i obiektów fizjograficznych ${ }^{19}$.

18 Dz. U. 2001, Nr 142, poz. 1591, z późn. zm.

19 Dz. U. 2003, Nr 166, poz. 1612. 
Rada gminy przedstawia wniosek, o używanie dodatkowych nazw ministrowi „właściwemu do spraw wyznań religijnych oraz mniejszości narodowych i etnicznych" za pośrednictwem wojewody - na żądanie mieszkańców gminy należących do mniejszości lub z inicjatywy własnej ${ }^{20}$. W przypadku wniosku dotyczącego nazwy miejscowości zamieszkanej, rada gminy jest obowiązana uprzednio przeprowadzić w tej sprawie konsultacje z mieszkańcami tej miejscowości, w trybie określonym w art. 5a ust. 2 ustawy o samorządzie gminnym. Wojewoda jest obowiązany przekazać ministrowi właściwemu do spraw wyznań religijnych oraz mniejszości narodowych i etnicznych wniosek nie później niż w ciągu 30 dni od dnia jego otrzymania, dołączając swoją opinię. Minister ,właściwy do spraw wyznań religijnych oraz mniejszości narodowych i etnicznych" przekazuje Komisji Nazw Miejscowości i Obiektów Fizjograficznych wniosek do zaopiniowania. Komisja przedstawia ministrowi właściwemu do spraw wyznań religijnych oraz mniejszości narodowych i etnicznych swoją opinię, za pośrednictwem ministra właściwego do spraw administracji publicznej, niezwłocznie po zapoznaniu się z wnioskiem.

Dodatkową nazwę miejscowości lub obiektu fizjograficznego w języku mniejszości uważa się za ustaloną jeżeli została wpisana do Rejestru gmin. Wpisu dokonuje minister „właściwy do spraw wyznań religijnych oraz mniejszości narodowych i etnicznych”, po uzyskaniu pozytywnej opinii Komisji Nazw Miejscowości i Obiektów Fizjograficznych. Ma on obowiązek odmówić wpisania do Rejestru gmin dodatkowej nazwy miejscowości lub obiektu fizjograficznego w języku mniejszości - jeżeli będzie nawiązywała ona do nazwy z okresu 1933-1945, nadanej przez władze Trzeciej Rzeszy Niemieckiej lub Związku Socjalistycznych Republik Radzieckich. Na odmowę dokonania wpisu, i na wykreślenie, radzie gminy przysługuje skarga do sądu administracyjnego. Minister „właściwy do spraw wyznań religijnych oraz mniejszości narodowych i etnicznych", został zobowiązany przez ustawę do określenia, w porozumieniu z ministrem właściwym do spraw administracji publicznej, w drodze rozporządzenia, wzorów wniosków rady gminy: o wpisanie gminy do wspominanego Rejestru gmin oraz o ustalenie dodatkowej nazwy miejscowości lub obiektu fizjograficznego w języku mniejszości.

Minister „,właściwy do spraw wyznań religijnych oraz mniejszości narodowych i etnicznych", został także zobowiązany przez ustawę, aby w porozumieniu z ministrem właściwym do spraw administracji publicznej, określił w drodze rozporządzenia, sposób prowadzenia Rejestru gmin oraz szczegółowy zakres informacji umieszczanych w tym Rejestrze, uwzględniając określenie województwa i powiatu, na których obszarze położona jest gmina, nazwę gminy, urzędową nazwę miejscowości lub obiektu fizjograficznego oraz dodatkową nazwę w języku mniejszości. Natomiast ministra

${ }^{20}$ Wniosek powinien zawierać: uchwałę rady gminy w sprawie ustalenia dodatkowej nazwy miejscowości lub obiektu fizjograficznego; prawidłowe brzmienie urzędowej nazwy miejscowości lub obiektu fizjograficznego w języku polskim; w przypadku obiektu fizjograficznego - opinie zarządów województw, na których terenie obiekt się znajduje; proponowane brzmienie nazwy dodatkowej w języku mniejszości; omówienie wyników konsultacji, o których mowa w ustawie; informację o kosztach finansowych wprowadzenia proponowanej zmiany. W myśl ustawy wymóg zasięgnięcia opinii uznaje się za spełniony w przypadku nie wyrażenia opinii w terminie $30 \mathrm{dni}$ od dnia wystąpienia o opinię. 
właściwego do spraw transportu, ustawodawca zobligował, aby w porozumieniu z ministrem ,właściwym do spraw wyznań religijnych oraz mniejszości narodowych i etnicznych" i ministrem właściwym do spraw administracji publicznej, do określenia, w drodze rozporządzenia, szczegółów dotyczących umieszczania na znakach i tablicach dodatkowych nazw w języku mniejszości, uwzględniając w szczególności wielkość i styl czcionki nazw w języku polskim i w języku mniejszości (Rozporzqdzenie, 2005d). Koszty związane z wprowadzeniem i używaniem na obszarze gminy języka pomocniczego oraz koszty związane z wprowadzeniem dodatkowych nazw, w języku mniejszości ponosi, z zastrzeżeniem budżet gminy, z tym, że koszty związane z wymianą tablic informacyjnych, wynikającą z ustalenia dodatkowej nazwy miejscowości lub obiektu fizjograficznego w języku mniejszości, ponosi budżet państwa.

Realizacja prawa osób należących do mniejszości do nauki języka mniejszości lub w języku mniejszości, a także prawa tych osób do nauki historii i kultury mniejszości odbywa się - w myśl ustawy - na zasadach i w trybie określonych w Ustawie o systemie oświaty z 7 września $1991 \mathrm{r}^{21}$ Organy władzy publicznej zostały przy tym zobowiązane do podejmowania odpowiednich działań w celu wspierania działalności zmierzającej do ochrony, zachowania i rozwoju tożsamości kulturowej mniejszości, w szczególności do dotacji celowych lub podmiotowych na: działalność instytucji kulturalnych, ruchu artystycznego i twórczości mniejszości oraz imprez artystycznych mających istotne znaczenie dla kultury mniejszości; inwestycje służące zachowaniu tożsamości kulturowej mniejszości; wydawanie książek, czasopism, periodyków i druków ulotnych w językach mniejszości lub w języku polskim, w postaci drukowanej oraz w innych technikach zapisu obrazu i dźwięku; wspieranie programów telewizyjnych i audycji radiowych realizowanych przez mniejszości; ochronę miejsc związanych z kulturą mniejszości; działalność świetlicowa; prowadzenie bibliotek oraz dokumentacji życia kulturalnego i artystycznego mniejszości; edukację dzieci i młodzieży realizowaną w różnych formach; propagowanie wiedzy o mniejszościach; inne programy realizujące cele, o których mowa w ust. 1, oraz wspierające integrację obywatelską mniejszości. Dotacje te przyznawane z części budżetu państwa, której dysponentem jest minister właściwy do spraw wyznań religijnych oraz mniejszości narodowych i etnicznych, mogą być udzielane z pominięciem otwartego konkursu ofert. Minister właściwy do spraw wyznań religijnych oraz mniejszości narodowych i etnicznych został zobowiązany do corocznego ogłaszania zasady postępowania w sprawach dotyczących udzielania dotacji. Minister właściwy do spraw oświaty i wychowania zobowiązany został do podjęcia działań w celu zapewnienia możliwości kształcenia nauczycieli oraz dostępu do podręczników na potrzeby szkół i placówek publicznych, a także do popularyzacji wiedzy o historii, kulturze, języku i o tradycjach religijnych mniejszości narodowych i etnicznych oraz społeczności posługującej się językiem regionalnym $^{22}$. Zmieniając Ustawę o radiofonii i telewizji z 29 grudnia $1992 \mathrm{r}^{23}$ zaliczono do zadań publicznej radiofonii i telewizji obowiązek uwzględniania potrzeb

21 Dz. U. 2004, Nr 256, poz. 2572, Nr 273, poz. 2703 i Nr 281, poz. 2781.

22 Uczyniono to odpowiednio uzupełniając art. 13 ustawy z 7 września 1991 r. o systemie oświaty (Dz. U. 2004, Nr 256, poz. 2572, Nr 273, poz. 2703 i Nr 281, poz. 2781).

${ }^{23}$ Uzupełniając treść art. 21 ustawy (Dz. U. 2004, Nr 253, poz. 2531). 
mniejszości narodowych i etnicznych oraz społeczności posługującej się językiem regionalnym, w tym emitowania programów informacyjnych w językach mniejszości narodowych i etnicznych oraz języku regionalnym. Zobowiązano także dyrektorów oddziałów jednostek publicznej radiofonii i telewizji, aby powołując rady programowe oddziałów emitujących programy w językach mniejszości narodowych i etnicznych oraz języku regionalnym, uwzględniali kandydatów zgłaszanych przez organizacje społeczne mniejszości narodowych i etnicznych oraz społeczności posługującej się językiem regionalnym.

W myśl ustawy organem administracji rządowej w sprawach objętych ustawą jest minister ,właściwy do spraw wyznań religijnych oraz mniejszości narodowych i etnicznych". Ma on sprzyjać realizacji praw i potrzeb mniejszości poprzez podejmowanie działań na rzecz mniejszości i inicjowanie programów dotyczących: zachowania i rozwoju tożsamości, kultury i języka mniejszości, przy zapewnieniu pełnej integracji obywatelskiej osób należących do mniejszości, realizacji zasady równego traktowania osób bez względu na pochodzenie etniczne. Ponadto winien współdziałać z właściwymi organami w zakresie przeciwdziałania naruszaniu praw mniejszości; dokonywać analiz i ocen sytuacji prawnej i społecznej mniejszości; upowszechniać wiedzę na temat mniejszości oraz jej kultury, a także inicjować badania nad sytuacją mniejszości, w tym w zakresie dyskryminacji oraz metodami i strategiami przeciwdziałania jej występowaniu. Na wojewodów ustawodawca nałożył natomiast obowiązek: koordynowania na obszarze województwa działań organów administracji rządowej, realizujących zadania na rzecz mniejszości; podejmowania działań na rzecz respektowania praw mniejszości i przeciwdziałania naruszaniu tych praw i dyskryminacji osób należących do mniejszości; podejmowania działań na rzecz rozwiązywania problemów mniejszości oraz ułatwiających respektowanie praw osób posługujących się językiem regionalnym. W celu realizacji tych zadań wojewoda został zobligowany do współdziałania z organami samorządu terytorialnego i organizacjami społecznymi, w szczególności z organizacjami mniejszości oraz opiniowania programów na rzecz mniejszości, realizowanych na terenie danego województwa. Wojewoda - zgodnie z ustawą - może ustanowić na czas nieoznaczony pełnomocnika do spraw mniejszości narodowych i etnicznych w trybie art. 35 Ustawy o administracji rzqdowej w województwie z 5 czerwca 1998 r. (Ustawa, 2001).

Ustawodawca zadeklarował także utworzenie Komisji Wspólnej Rzq̨du i Mniejszości Narodowych i Etnicznych (dalej: Komisja wspólna, komisja) jako organu opiniodawczo-doradczego Prezesa Rady Ministrów ${ }^{24}$. Do zadań komisji zaliczono: wyrażanie

${ }^{24}$ W skład komisji wchodzą: przedstawiciele organów administracji rządowej, a mianowicie ministrów właściwych do spraw: wyznań religijnych oraz mniejszości narodowych i etnicznych; administracji publicznej; kultury i ochrony dziedzictwa narodowego; oświaty i wychowania; finansów publicznych; pracy; wewnętrznych; zabezpieczenia społecznego; spraw zagranicznych; ministra sprawiedliwości. Ponadto Prezesa Gtównego Urzędu Statystycznego, Rady Ochrony Pamięci Walk i Męczeństwa, Szefa Kancelarii Prezesa Rady Ministrów oraz przedstawiciele mniejszości - po dwóch reprezentantów mniejszości: białoruskiej, litewskiej, niemieckiej, ukraińskiej, łemkowskiej; po jednym przedstawicielu mniejszości: czeskiej, ormiańskiej, rosyjskiej, słowackiej, żydowskiej, karaimskiej, romskiej, tatarskiej; wreszcie dwóch przedstawicieli społeczności posługującej się językiem regionalnym, a także sekretarz Komisji wspólnej, którym jest pracownik urzędu obsługującego 
opinii w sprawach realizacji praw i potrzeb mniejszości, w tym oceny sposobu realizacji tych praw oraz formułowanie propozycji w zakresie działań zmierzających do zapewnienia realizacji praw i potrzeb mniejszości; opiniowanie programów służących tworzeniu warunków sprzyjających zachowaniu i rozwojowi tożsamości kulturowej mniejszości oraz zachowaniu i rozwojowi języka regionalnego; opiniowanie projektów aktów prawnych dotyczących spraw mniejszości; opiniowanie wysokości i zasad podziału środków przeznaczonych w budżecie państwa na wspieranie działalności zmierzającej do ochrony, zachowania i rozwoju tożsamości kulturowej mniejszości oraz zachowania i rozwoju języka regionalnego; podejmowanie działań na rzecz przeciwdziałania dyskryminacji osób należących do mniejszości.

W celu realizacji swoich zadań Komisja Wspólna: współdziała z organami administracji rządowej i samorządu terytorialnego oraz z zainteresowanymi organizacjami

ministra właściwego do spraw wyznań religijnych oraz mniejszości narodowych i etnicznych. W myśl rozporządzenia Rady Ministrów z 12 lutego 2010 r. w sprawie włączenia w skład Komisji Wspólnej Rzq̨du i Mniejszości Narodowych i Etnicznych przedstawiciela ministra właściwego do spraw szkolnictwa wyższego (Dz. U. 2010, Nr 28, poz. 148) w skład wspomnianej komisji został włączony przedstawiciel ministra właściwego do spraw szkolnictwa wyższego. Członków komisji powołuje i odwołuje Prezes Rady Ministrów na wniosek ministra właściwego do spraw wyznań religijnych oraz mniejszości narodowych i etnicznych Poszczególne mniejszości oraz społeczność posługująca się językiem regionalnym, o którym mowa w art. 19 ustawy, zgłaszają ministrowi „właściwemu do spraw wyznań religijnych oraz mniejszości narodowych i etnicznych” swoich kandydatów na członków komisji w liczbie określonej dla tej mniejszości lub dla tej społeczności odpowiednio w terminie 90 dni od dnia otrzymania zawiadomienia. Jeżeli w tym terminie któraś z mniejszości lub społeczność posługująca się językiem regionalnym nie zgłosi swoich kandydatów lub zgłosi liczbę kandydatów inną niż określona odpowiednio dla tej mniejszości, wówczas minister „właściwy do spraw wyznań religijnych oraz mniejszości narodowych i etnicznych” przedstawia tej mniejszości lub społeczności do zaopiniowania swoich kandydatów na członków Komisji Wspólnej reprezentujących tę mniejszość lub społeczność. W przypadku niewyrażenia przez mniejszość lub społeczność opinii w terminie 30 dni od dnia przedstawienia przez ministra właściwego do spraw wyznań religijnych oraz mniejszości narodowych i etnicznych kandydatów, wymóg uzyskania opinii uznaje się za spełniony. Minister właściwy do spraw wyznań religijnych oraz mniejszości narodowych i etnicznych występuje do Prezesa Rady Ministrów z wnioskiem o odwołanie członka Komisji Wspólnej w przypadku: złożenia przez członka rezygnacji z członkostwa w Komisji Wspólnej; wystąpienia przez organ lub mniejszość lub społeczność posługującą się językiem regionalnym, których przedstawicielem jest członek, do ministra właściwego do spraw wyznań religijnych oraz mniejszości narodowych i etnicznych, z uzasadnionym wnioskiem o odwołanie członka ze składu Komisji wspólnej; skazania członka prawomocnym wyrokiem sądu za przestępstwo popełnione z winy umyślnej. Członkostwo wygasa w razie śmierci. Rada Ministrów może włączyć w skład komisji, w drodze rozporządzenia, przedstawiciela organu administracji rządowej innego niż wymieniony w ustawie. Współprzewodniczącymi komisji są: przedstawiciel ministra właściwego do spraw wyznań religijnych oraz mniejszości narodowych i etnicznych oraz przedstawiciel mniejszości oraz społeczności posługującej się językiem regionalnym, wybrany przez członków. Współprzewodniczących Komisji Wspólnej powołuje i odwołuje Prezes Rady Ministrów na wniosek ministra właściwego do spraw wyznań religijnych oraz mniejszości narodowych i etnicznych. Obsługę organizacyjno-techniczną prac komisji zapewnia urząd obsługujący ministra właściwego do spraw wyznań religijnych oraz mniejszości narodowych i etnicznych. Regulamin pracy Komisji Wspólnej Rzq̨du i Mniejszości Narodowych $i$ Etnicznych stanowi załącznik do zarządzenia nr 74 Prezesa Rady Ministrów z 22 lipca 2007 r. w sprawie regulaminu pracy Komisji Wspólnej Rządu i Mniejszości Narodowych i Etnicznych (MP 2007, Nr 45, poz. 534). Warto zauważyć, że w ramach komisji działają trzy stałe zespoły problemowe: ds. edukacji, ds. kultury i mediów i ds. romskich. W tej ostatniej zasiada też członek reprezentujący mniejszość romską. 
społecznymi; może zwracać się do instytucji, placówek i środowisk naukowych oraz organizacji społecznych w szczególności o opinie, stanowiska, ekspertyzy lub informacje; może zapraszać do udziału w swoich pracach przedstawicieli jednostek samorządu terytorialnego, organizacji społecznych i środowisk naukowych.

Posiedzenia Komisji Wspólnej odbywają się nie rzadziej niż raz na 6 miesięcy. Posiedzenia zwołuje współprzewodniczący komisji, będący przedstawicielem ministra właściwego do spraw wyznań religijnych oraz mniejszości narodowych i etnicznych, z inicjatywy własnej lub na wniosek współprzewodniczącego, będącego przedstawicielem mniejszości i społeczności posługującej się językiem regionalnym. Ustawa szczegółowo reguluje tryb pracy komisji oraz prawa i obowiązki jej członków. Koszty funkcjonowania Komisji Wspólnej są pokrywane z budżetu państwa z części, której dysponentem jest minister właściwy do spraw wyznań religijnych oraz mniejszości narodowych i etnicznych.

Organy administracji rządowej, samorządu terytorialnego oraz organizacje mniejszości oraz społeczności posługującej się językiem regionalnym, zostały zobowiązane do przekazywania ministrowi właściwemu do spraw wyznań religijnych oraz mniejszości narodowych i etnicznych, na jego wniosek, informacji pozostających w zakresie działania tych organów lub organizacji i dotyczących sytuacji mniejszości oraz społeczności posługującej się językiem regionalnym lub realizacji zadań na rzecz mniejszości lub zachowania i rozwoju języka. Minister „właściwy do spraw wyznań religijnych oraz mniejszości narodowych i etnicznych" został z mocy ustawy zobowiązany do przygotowywania, nie rzadziej niż raz na dwa lata, raportu dotyczącego sytuacji mniejszości w Rzeczypospolitej Polskiej. Raport podlega zaopiniowaniu przez Komisję Wspólną. Raport wraz ze wspomnianą opinią, są przekazywane Radzie Ministrów, a następnie - po zatwierdzeniu raportu przez Radę Ministrów - publikowane przez ministra ,właściwego do spraw wyznań religijnych oraz mniejszości narodowych i etnicznych" w formie elektronicznej. Organy administracji rządowej, samorządu terytorialnego oraz organizacje pozarządowe ustawa zobowiązała do przekazywania wojewodzie, w celu zaopiniowania, dokumentów dotyczących programów realizowanych z ich udziałem na terenie województwa, dotyczących mniejszości lub zachowania i rozwoju języka regionalnego, finansowanych w całości lub części ze środków publicznych.

Ustawa o mniejszościach narodowych $i$ etnicznych oraz o języku regionalnym niewatpliwie odpowiada standardom europejskim zapełniając dotkliwą lukę istniejącą w zakresie regulacji praw mniejszości w prawodawstwie polskim. Ustawa ta daleka jest jednak od doskonałości. Pomijając niedostatki legislacyjne, , ,chropowatości” językowe, pewną fasadowość powoływanych organów i instytucji wypada zauważyć, że nie rozwiązuje ona wielu poważnych problemów społecznych. Sztucznie ograniczając pojęcia „mniejszości narodowej” i „mniejszości etnicznej” tylko do grup obywateli polskich i to wyłącznie takich, których przodkowie zamieszkiwali obecne terytorium polski od co najmniej stu lat ustawa pozostawiła poza obrębem swoich regulacji znaczące grupy ludności z tej tylko racji, że jej przedstawiciele nie posiadają obywatelstwa polskiego albo dlatego, że nie zamieszkują oni na obszarze Rzeczypospolitej Polski od co najmniej stu lat. Godzi się zauważyć, że w tej grupie znaleźli się zarówno mieszkający w Polsce Amerykanie, Francuzi, jak i niezmiernie liczni Wietnamczycy, 
a także niezmiernie liczni Grecy, Włosi, Bułgarzy, Anglicy, Kanadyjczycy i Arabowie. Oczywiście można twierdzić, że ich sytuację regulują akty prawa międzynarodowego dotyczące uchodźców i emigrantów, ale w gruncie rzeczy te grupy pozbawiono ochrony i nie dano im prawnych gwarancji możliwości rozwoju tożsamości kulturowej i językowej. Formalnie rzecz biorąc, taka sytuacja nie narusza norm prawa międzynarodowego nie mniej jednak wydaje się być sprzeczna $\mathrm{z}$ ich duchem.

Wydaje się, że okres jedenastu lat, jaki upłynął od przeprowadzenia spisu musiał zmienić - przynajmniej w pewnym stopniu - strukturę mniejszości narodowych. Obserwując zmiany demograficzne na świecie można przypuszczać, iż zwiększyła się w Polsce populacja Amerykanów, Wietnamczyków, Chińczyków, Turków. Napłynęli też być może Czeczeni, których w 2002 r. było tylko 49, Gruzini i Kazachowie. Niewątpliwie część członków mniejszości to uciekinierzy polityczni, w tej grupie należałoby się spodziewać zwłaszcza Czeczenów, być może także Arabów z różnych państw, nie można także pomijać imigracji zarobkowej. Pobieżna obserwacja nakazywałaby doszukiwać się wśród nich Chińczyków, Wietnamczyków, Palestyńczyków.

W okresie II Rzeczpospolitej problem mniejszości narodowej wywoływał szereg nieporozumień, prowadząc do poważnych częstokroć zamieszek. W pierwszych latach II Rzeczpospolitej w polityce państwa kwestie mniejszości narodowych nie miały priorytetowej roli. Próbę uregulowania problemów narodowościowych i wypracowania zasad polityki wobec mniejszości podjął rząd Władysława Sikorskiego, akcentujący potrzebę rozwiązania kwestii osadnictwa wojskowego na kresach, usprawnienia administracji polskiej i uregulowanie relacji między państwem a kościołami mniejszościowymi. Późniejszy rząd hieno piasta, realizując program wynikający z „paktu lanckorońskiego”, zmierzał do ograniczenia uprawnień i stanu posiadania mniejszości, rozszerzenia uprawnień Kościoła katolickiego, zwalczając niektóre ugrupowania ukraińskie i białoruskie. Podjął także restrykcyjne działania wobec Żydów. Rząd W. Grabskiego podejmował próby rozwiązania konfliktów między państwem a mniejszościami w kwestii szkolnictwa, języka i kościołów. Po zamachu majowym podjęto próbę wprowadzenia w życie koncepcji asymilacji, którą starano się połączyć z reformą rolną oraz sanacją ekonomiczną Kresów. Nie wypracowano wówczas jednak jednolitego modelu polityki narodowościowej, starano się generalnie realizować politykę asymilacji państwowej umożliwiając mniejszościom rozwój narodowy na bazie lojalności, legalizmu i wspólnej odpowiedzialności za państwo. Jednocześnie jednak zwalczano mniejszość niemiecka, starając się, z małymi skutkami, przezwyciężyć wrogość między Polakami a Ukraińcami na Wołyniu. Z drugiej strony, podjęto działania zmierzające do rozbicia ruchu narodowego mniejszości białoruskiej. Po śmierci J. Piłsudzkiego doszło do powołania 19 grudnia 1935 r. Komitetu do spraw Narodowościowych, który odszedł od idei asymilacji, zastępując ją programem umacniania polskości. Jednocześnie doszło do napięć w stosunkach polsko-litewskich oraz polsko-ukraińskich. W tym ostatnim przypadku na tle żądań autonomii dla województw południowo-wschodnich. Polityka władz II Rzeczpospolitej przeszła znamienną rewolucję od haseł polonizacji poprzez program asymilacji narodowej, potem państwowej, do koncepcji umacniania polskości. Faworyzowano przy tym ugrupowania przyjazne Rzeczpospolitej (Chojnowski, 1979; Tomaszewski, 1985a; Tomaszewski, 1985b: 50; Tomaszewski, 1997; Halczak, 1996; Krysiński, 1933; Olszewicz, 1938; Eberhardt, 1996: 101; Mich, 1994; Mich, 1993; 
Paruch, 1997; Polska myśl, 1992; Koko, 1995; Mniejszości narodowe, 1988; Gomułka, 1989).

Po II wojnie światowej ludność Polski stała się bardziej jednorodna narodowościowo, niż miało to miejsce w okresie międzywojennym. Polskę opuściły ponad trzy miliony Niemców, blisko milion Ukraińców, 36 tysięcy Białorusinów i według różnych szacunków od tysiąca do 50 tysięcy Litwinów. Na sytuację mniejszości ukraińskiej nakładał się problem działania UPA. Praktycznie od zakończenia II wojny światowej dochodziło do spontanicznie podejmowanych prób pogromów ludności żydowskiej. Pozytywny stosunek władz do ludności żydowskiej uległ istotnej zmianie po powstaniu państwa Izrael. W późniejszym czasie, po wypadkach marcowych 1968 r. ujawniły się w dużej mierze inspirowane przez władze postawy ksenofobii i szowinizmu, przede wszystkim wobec osób pochodzenia żydowskiego. W wyniku nagonki antysemickiej do opuszczenia Polski zmuszono wielu Żydów oraz Polaków uznanych za Żydów (Elsner, 1991). Starano się przyspieszyć procesy asymilacyjne i objąć nadzorem działalność organizacyjną wszystkich mniejszości narodowych (Łodziński, 1992; Madajczyk, 1995; Pudło, 1993: 153-162; Chałupczak, Browarek, 1998: 263-294).

Zmiana systemu politycznego w 1989 r., przyjęcie modelu demokratycznego, poprzedzona wejściem Polski do systemu KBWE/OBWE oraz Rady Europy, co nastąpiło 26 listopada 1991 r., a następnie w skład Unii Europejskiej pozwalało na przypuszczenie, że organy Rzeczpospolitej oraz jej obywatele będą przestrzegać standardów międzynarodowych w zakresie praw mniejszości narodowych. Tymczasem możliwość wyrażania w sposób nieskrępowany opinii, przywrócona wolność wypowiedzi i wolność prasy, pozwoliła na zamanifestowanie przez wcale nie małe grupy obywateli postaw rasistowskich, ksenofobicznych, nacjonalistycznych i antysemickich. Niemały wpływ na publiczne artykułowanie w środkach społecznego przekazu, na forach internetowych, przy okazji rozmaitych manifestacji tego rodzaju poglądów miała także postawa wielu hierarchów i duchownych Kościoła rzymskokatolickiego. Obiektem słownych napaści stali się najpierw Żydzi, traktowani jako wróg symboliczny, gdyż mniejszość ta jest obecnie w Polsce znikoma, potem jednostki, niemające korzeni żydowskich, ale z jakiś przyczyn uznawane przez otoczenie i motłoch za Żydów lub osoby przychylne Żydom, judaizmowi i udzielające obecnie bądź w przeszłości pomocy przedstawicielom tej nacji. Po dzień dzisiejszy trwa w niektórych tytułach prasy drukowanej, a zwłaszcza w internecie, gorączkowe sprawdzanie czy osoby pełniące odpowiedzialne funkcje polityczne bądź zajmujące stanowiska w aparacie państwowym nie mają przypadkowo korzeni żydowskich. Co jakiś czas różne organizacje bądź jednostki publikują listy osób uznawanych za Żydów. Bycie Żydem w opinii znaczącej części społeczeństwa godne jest napiętnowania.

Społeczność żydowska jest, jak wspomniano wyżej, niewielka i świetnie zorganizowana, mogąca liczyć na wsparcie z zagranicy, antysemityzm uznawany jest przy tym dość powszechnie na Zachodzie za zjawisko co najmniej wstydliwe. Dlatego na pozycję ,wroga” zepchnięto, przynajmniej po 11 września 2001 r., wyznawców islamu, zarówno przybyszów z krajów muzułmańskich, zwłaszcza arabskich, jak i mocno zasymilowanych, osiedlonych w Rzeczpospolitej od XIV w. Tatarów, nawet jeżeli nie są już wyznawcami islamu. Nastroje antyislamskie, a co za tym idzie antytatarskie, doszły oczywiście do głosu tam, gdzie takie grupy są osiedlone, zwłaszcza na północ- 
no-wschodnich ziemiach Polski, w Gdańsku i okolicach, w Białymstoku oraz w Warszawie. Zaczepiano tych wyznawców islamu, w tym także Tatarów, którzy otwarcie identyfikowali się ze swoją religią i narodowością, uciekano się do gróźb pod ich adresem, co zmusiło część z nich do zmiany imion na takie, które nie identyfikowały ich $\mathrm{z}$ islamem. Niszczono mizary (cmentarze tatarskie), atakowano kilkakrotnie gdański meczet, obrzucając go kamieniami, wybijając szyby, a potem podpalając; usiłowano zniszczyć meczet w Białymstoku, w Warszawie podjęto, w gruncie rzeczy udaną, próbę uniemożliwienia budowy meczetu i ośrodka kultury muzułmańskiej (Piotrowski, 2010: 25-26). Starano się także uniemożliwić odbycie islamskiego zjazdu religijnego w Puławach ${ }^{25}$ (Gąsior, 2013a; Gąsior, 2013b; Nie dla islamizacji). Do ataków, na szczęście jedynie werbalnych, na społeczność tatarską doszło w 2013 r. przy okazji dyskusji dotyczącej możliwości uboju rytualnego, kiedy to grupa „obrońców zwierząt” usiłowała wedrzeć się na ogrodzony teren wokół meczetu w Bohonikach, uniemożliwiając obrzędy religijne. Szermujący hasłami antyislamskimi nie zauważali przy tym faktu asymilacji kulturowej osiedlonych w Rzeczpospolitej Tatarów oraz faktu, że toczą oni trudną i niezauważalną walkę, stawiając tamę podejmowanym z inspiracji ośrodków arabskich próbom reislamizacji, zmierzającym w efekcie do zniszczenia tradycji tatarskiej i poczucia odrębności w tej nacji nie tylko od chrześcijańskich mieszkańców Polski, lecz także od arabskich i tureckich wyznawców islamu. Nie odróżnia się przy tym Muzutmańskiego Zwiazku Religijnego, zdominowanego przez Tatarów, od Ligi Muzutmańskiej w RP, powstałej formalnie dopiero w 2004 r. z połączenia Stowarzyszenia Studentów Muzulmańskich oraz Muzulmańskiego Stowarzyszenia Kształcenia Kulturalnego, skupiającego tych studentów z krajów muzułmańskich i arabskich, którzy pozostali w Polsce, nie zauważając, że obie organizacje mają niezależnych od siebie muftich.

Z niechęcią większości katolickich mieszkańców Polski spotykają się także Karaimi mieszkający we Wrocławiu i w Warszawie, prawosławni poza obszarami, gdzie stanowią większość, a nawet nieliczni przecież Ormianie. Odmienność religii w państwie zdominowanym przez rzymskokatolików bardzo silnie stygmatyzuje. $Z$ niechęcią spotykają się przecież świadkowie Jehowy i zielonoświątkowcy, mimo iż nawet najbardziej zajadli wrogowie tych dwóch konfesji nie mogą odmówić wyznawcom obu religii tego, że przestrzegają oni w życiu codziennym niezwykle wysokich standardów moralnych.

Niechęć do obcych jest w warunkach polskich bardzo znamienna. Obcym może być przy tym przybysz z innego regionu Rzeczpospolitej, nawet jeśli w jego ubiorze, zachowaniu czy mowie trudno zauważyć odmienności. $Z$ niechęcią przecież spotykają

${ }^{25}$ W ramach zjazdu organizowanego przez Ligę Muzułmańską w RP planowane są m.in. wspólne modlitwy, seminaria dla kobiet i dzieci oraz wydarzenia sportowe i artystyczne. Po informacji o zamiarze odbycia zjazdu na Facebooku powstał profil, na którym mieszkańcy Puław zachęcają do zorganizowania demonstracji w dniach zjazdu. Do tej pory chęć udziału zadeklarowały 334 osoby, w tym także Sławomir Kamiński, były starosta puławski, a obecnie radny powiatowy. Charakterystyczne są także wpisy internautów zawierające następujące stwierdzenia: „Niech wypier****** z Polski albo siedzą cicho w domach, brudasy jedne, zjazdów im się zachciało”, „Po co w Puławach, zapraszamy na Majdanek”, „Właśnie w takich momentach liczę na naszych kochanych kibiców. Zjednoczcie się i pokażcie im, gdzie ich miejsce". 
się reemigranci przybywający z terenów byłego ZSRR, zwłaszcza z Kazachstanu i z Syberii. Jest przy tym rzeczą interesująca, że grupa Polaków, którą po wielu perypetiach i mitręgach administracyjnych sprowadzono $\mathrm{z}$ tego obszaru, jest stosunkowo niewielka i nie potrafiono opracować żadnego programu pozwalającego na pełną asymilację i adaptację tej ludności w nowym środowisku. Konstatacja ta jest szczególnie niepokojąca, zważywszy że władze Republiki Federalnej Niemiec zdecydowały się na przesiedlenie z terytorium Kazachstanu ponad stutysięcznej grupy swoich rodaków, opracowując dla nich szczegółowy program adaptacyjny. Niechęć do „obcych” przedstawicieli innych narodów jest całkowicie niezrozumiała jeśli zważyć, że przez cały wiek XIX Polacy po powstaniach i rewolucjach zmuszeni byli szukać schronienia w państwach Europy Zachodniej, gdzie spotykali się generalnie z życzliwym przyjęciem, które słabło w miarę jak ludność miejscowa zaczęła się orientować w wewnętrznych sporach, jakie toczyli członkowie tej emigracji. W tej sytuacji niezrozumiałe jest tworzenie barier administracyjnych dla uchodźców z Czeczenii, niektórych państw azjatyckich bądź afrykańskich (Chlebny, 2002: 47-59; Chlebny, 2010a: 124-143; Chlebny, 2002a: 150-158; Chlebny, 2010b: 37-49; Sobczak, 2010: 124-145; Potyrała, 2005; Oleksiewicz, 2006). Szermowanie hasłami trudności finansowych w najmniejszym stopniu nie usprawiedliwia sposobu, w jaki traktowani są uchodźcy w niektórych ośrodkach, przypominających swym wyglądem i regulaminem raczej więzienia bądź obozy.

Mniejszości narodowe w Polsce są niewielkie, nie odgrywają - poza mniejszością niemiecką - żadnej roli politycznej, służą jednak większości członków społeczeństwa polskiego jako przysłowiowy „kozioł ofiarny”, wygodny „, chłopiec do bicia”, którego można obarczyć winą za wszelkie klęski i niepowodzenia doznawane przez etnicznych Polaków, w większości rzymskokatolików. Mniejszości narodowe nie są zagrożeniem dla bezpieczeństwa Polski, mimo że podejmowane są próby infiltracji tych środowisk przez służby specjalne (Skrzeszewski, 2007: 5; Skrzeszewski, 2005: 5). Prześladowanie przedstawicieli tych mniejszości może jednak godzić w i tak niski prestiż Polaków za granica.

\section{Bibliografia}

Barcz J. (1986), Definicja mniejszości narodowych, „Stosunki Międzynarodowe”, nr 11.

Barcz J. (1996), Klauzule dotyczqce praw mniejszości narodowych w nowych dwustronnych traktatach Polski z państwami sasiedzkimi, „Przegląd Zachodni”, nr 2.

Byczkowsk J. (1977), Problemy mniejszości narodowych w działalności ONZ, „Studia Śląskie”, rok 21 .

Chałupczak H., Browarek T. (1998), Mniejszości narodowe w Polsce 1918-1995, Lublin.

Chlebny J. (2010a), Europejskie standardy w postępowaniach w sprawach o nadanie statusu uchodźcy, w: Europejska przestrzeń sqdowa, (red.) M. Bojarski, A. Frąckowiak-Adamska, R. Grzeszczak, Wrocław.

Chlebny J. (2002a), Ochrona sqdowa w sprawach o nadanie statusu uchodźcy, w: Ochrona uchodźców. Dziesiata rocznica przystapienia Polski do Konwencji Genewskiej, Warszawa.

Chlebny J. (2011), Postępowanie w sprawie o nadanie statusu uchodźcy, Warszawa. 
Chlebny J. (2010b), Rozpoznanie ponownego wniosku o nadanie statusu uchodźcy, w: Uchodźcy w Polsce i Europie. Stan prawny i rzeczywistość, (red.) T. Gardocka, J. Sobczak, Torun.

Chlebny J. (2002b), Zagadnienia proceduralne w sprawach o nadanie statusu uchodźcy w orzecznictwie NSA, „Państwo i Prawo”, nr 5.

Chojnowski A. (1979), Koncepcje polityki narodowościowej rządów polskich w latach 1921-1939, Wrocław-Warszawa-Kraków.

Eberhardt P. (1996), Między Rosja a Niemcami. Przemiany narodowościowe w Europie Środkowo-Wschodniej, Warszawa.

Gąsior M. (2013), Polscy muzułmanie organizuja zjazd w Puławach. A internauci: „Kibice, zróbcie porzqdek”, „Ciapatych na stos”, natemat.pl, http://natemat.pl/63607,polscy-muzulmanie-organizuja-zjazd-w-pulawach-internauci-kibice-zrobcie-porzadek-ciapatym-na-stos-zapraszamy-na-majdanek, 29.12.2013.

Gąsior M. (2013), , To my zrobimy wam w Polsce dzihad!” - Polska Liga Obrony na pierwszym froncie wojny z muzulmanami, natemat.pl, http://natemat.pl/82531,to-my-zrobimy-wam-w-polsce-dzihad-polska-liga-obrony-na-pierwszym-froncie-wojny-z-muzulmanami, 29.12.2013.

Garlicki L. (2003), Komentarz do art. 35 Konstytucji, w: Konstytucja Rzeczypospolitej Polskiej. Komentarz, t. III, Warszawa.

Garlicki Z. (1993), Zapisy konstytucyjne dotyczace mniejszości narodowych i etnicznych - praktyka polska, „Materiały i Dokumenty” nr 52, BSE, Kancelaria Sejmu, Warszawa.

Gebethner S. (2001), Wybory do Sejmu i do Senatu. Komentarz do ustawy z dnia 12 kwietnia 2001 r. - Ordynacja wyborcza do Sejmu Rzeczypospolitej Polskiej i do Senatu Rzeczypospolitej Polskiej, Warszawa.

Gomułka K. (1989), Polskie ugrupowania polityczne wobec kwestii białoruskiej 1918-1922, Warszawa.

Gudaszewski G. (2006), Demograficzno-społeczna charakterystyka obywateli polskich deklarujacych ,narodowość niepolska” w Narodowym Spisie Powszechnym z 2002 roku, w: Mniejszości narodowe w świetle Narodowego Spisu Powszechnego z 2002 roku, L. Adamczuk, S. Łodziński, Warszawa.

Halczak B. (1996), Cele polityki endeckiej wobec mniejszości żydowskiej w Polsce w latach 1919-1926, „Biuletyn Żydowskiego Instytutu Historycznego”, nr 2-3.

Higgins R. (1994), Minority Rights Discrepancies and Divergencies Between the International Covenaut and the Council of Europe System, w: Liber amicorum for Henry Schermers, Dordrecht.

Janusz G., Bajda P. (2000b), Prawa mniejszości narodowych. Standardy Europejskie, Warszawa.

Janusz J., Bajda P. (2000a), Ochrona mniejszości. Standardy europejskie, Warszawa.

Kallas M. (1995), Prace parlamentarne nad uregulowaniem statusu mniejszości w Polsce (1989-1995), „Przegląd Sejmowy”.

Koko E. (1995), W nadziei na zgodę. Polski Ruch Socjalistyczny wobec kwestii narodowościowej w Polsce (1918-1939), Gdańsk.

Krysiński A. (1933), Ludność polska a mniejszości w Polsce w świetle spisów ludności 1921 i 1931, Warszawa.

Les droits des minorities en Europe. Vers un regime trans national (1997), (red.) H. Miall, Paris-Montreal.

Ludność wedtug narodowości, płci oraz miejsca zamieszkania w roku 2002, http://www.stat.gov.pl/ gus/5840_4520_PLK_HTML.htm, 2.01.2014.

Łodziński S. (2003), Problemy dyskryminacji osób należqcych do mniejszości narodowych i etnicznych w Polsce (polityka państwa, regulacje prawne i nastawienia społeczne, Kancelaria 
Sejmu, Biuro Studiów i Ekspertyz. Wydział Analiz Ekonomicznych i Społecznych, Raport nr 219.

Łodziński S. (2005), Równość różnica. Mniejszości narodowe w porzqdku demokratycznym w Polsce po 1989 roku, Warszawa.

Łodziński S. (1992), Struktura mniejszościowa Polski i polityka państwa wobec mniejszości w latach 1989-1992, „Kultura i Społeczeństwo”, nr 3.

Łodziński S. (2006), Trauma i władza liczb. Wybrane problemy społecznego odbioru pytania o „, narodowość" w Narodowym Spisie Powszechnym z 2002 roku, w: Mniejszości narodowe w Polsce w świetle Narodowego Spisu Powszechnego z 2002 roku, (red.) L. Adamczuk, S. Łodziński, Warszawa.

Madajczyk P. (1995), Mniejszości narodowe a Październik 1956 roku, „Dzieje Najnowsze”, nr 1.

Mich W. (1993), Problem mniejszości niemieckiej w myśli politycznej polskiej prawicy (1918-1939), „Przegląd Zachodni”, nr 3.

Mich W. (1994), Obcy w polskim domu. Nacjonalistyczne koncepcje rozwiazania problemu mniejszości narodowych 1918-1939, Lublin.

Mik C. (1996), Ochrona mniejszości narodowych w prawie europejskim, „Państwo i Prawo”, z. 3.

Mikołajczyk B. (1969), Mniejszości prawa międzynarodowego, Katowice.

Mikołajczyk B. (1996), Mniejszości w prawie międzynarodowym, Katowice.

Minderheiten (1974), „Forschung und Information”, Berlin, B. 17, 19.

Mniejszości narodowe w polskiej myśli politycznej XX wieku (1988), (red.) J. Jachymek, Łódź.

Nie dla Islamizacji Europy, https://pl-pl.facebook.com/pages/Nie-dla-Islamizacji-Europy/182944451832138, 29.12.2013.

Nowy Europejski Trybunat Praw Człowieka. Wybór orzeczeń 1999-2004 (2005), (oprac.) M. A. Nowicki, Kraków.

Oleksiewicz I. (2006), Uchodźcy w Unii Europejskiej. Aspekty prawne i polityczne, Bydgoszcz-Rzeszów.

Olszewicz B. (1938), Obraz Polski dzisiejszej. Fakty, cyfry i tablice, Warszawa.

Opinia w sprawie zgodności komisyjnego projektu ustawy o mniejszościach narodowych i etnicznych w Rzeczpospolitej Polskiej z prawem Unii Europejskiej (2002), Biuro Ekspertyz i Analiz Sejmowych.

Paruch W. (1997), Od konsolidacji państwowej do konsolidacji narodowej. Mniejszości narodowe w myśli politycznej obozu pitsudczykowskiego (1926-1939), Lublin.

Pawlak S. (2001), Ochrona mniejszości narodowych w Europie, Warszawa.

Polska myśl polityczna XIX i XX wieku. Polska - Polacy - Mniejszości narodowe (1992), (red.) W. Wrzesiński, Wrocław-Warszawa-Kraków.

Potyrała A. (2005), Współczesne uchodźstwo. Próby rozwiazania międzynarodowego problemu, Poznań.

Prawne aspekty mniejszości narodowych w Polsce (1993), BSE „Materiały i Dokumenty”, nr 52.

Pudło K. (1993), Polityka państwa polskiego wobec ludności ukraińskiej 1944-1991, „Sprawy Narodowościowe. Seria Nowa", t. 2, z. 1.

Radley N. (1995), Conceptual Problems in the Protection of Minorities. International Legal Developments, „Human Rights Quarterly”, Vol. 17.

Recommendation 1134/1990 on the Rights of Minorities, Adopted on 1 October 1990 (1990), Parliamentary Assembly of the Council of Europe, Strasburg. 
Rokkan S. (1983), Economy, Territory, Identity. Politics of West European Peripheries, London-Beverly Hills.

Rozporzadzenie Ministra Spraw Wewnętrznych i Administracji z dnia 30 maja 2005 r. w sprawie sposobu transliteracji imion i nazwisk osób należacych do mniejszości narodowych i etnicznych zapisanych $w$ alfabecie innym niż alfabet laciński (2005a), Dz. U., Nr 102, poz. 855.

Rozporzadzenie Ministra Spraw Wewnętrznych i Administracji z dnia 30 maja 2005 r. w sprawie Rejestru gmin, na których obszarze sq używane nazwy w języku mniejszości, wzorów wniosków o wpisanie do tego Rejestru oraz ustalenia dodatkowej nazwy miejscowości lub obiektu fizjograficznego w języku mniejszości narodowej lub etnicznej albo w języku regionalnym (2005b), Dz. U., Nr 102, poz. 887.

Rozporzadzenie Ministra Spraw Wewnętrznych i Administracji z dnia 16 czerwca 2005 r. w sprawie dyplomów, zaświadczeń lub certyfikatów potwierdzajacych znajomość języka pomocniczego (2005c), Dz. U., Nr 119, poz. 1013.

Rozporzadzenie Ministra Infrastruktury z dnia 10 sierpnia w sprawie umieszczania na znakach i tablicach dodatkowych nazw w językach mniejszości narodowych i etnicznych oraz w języku regionalnym (2005d), Dz. U., Nr 157, poz.1320.

Skóra A. (2005), Wniesienie podania w języku mniejszości narodowej do organu administracji publicznej, „Gdańskie Studia Prawnicze”, nr 14.

Skrzeszewski M. (2007), Przejawy dystansu społecznego wobec innych narodów i religii. Komunikat z badań, CBOS, Warszawa.

Skrzeszewski M. (2006), Stosunek Polaków do innych narodów. Komunikat z badań, CBOS, Warszawa.

Sobczak J. (2003), Wokół problemu definicji mniejszości narodowych, „Środkowoeuropejskie Studia Polityczne", nr 1.

Sobczak J. (2008), Mniejszości narodowe w polskim porzadku prawnym, w: Zderzenie czy dialog państw narodowych w Europie?, (red.) J. Sobczak, A. W. Mikołajczak, B. Hordecki, Poznań.

Sobczak J. (2009), Europejska Karta Języków Regionalnych lub Mniejszościowych jako instrument integracji międzynarodowej, „Rocznik Integracji Europejskiej”, nr 3.

Sozański J. (2002), Ochrona mniejszości w systemie uniwersalnym europejskim i wspólnotowym, Warszawa.

Suchocka M. (1991), Prawa mniejszości etnicznych, religijnych i językowych, w: Prawa człowieka. Model prawny, (red.) R. Wieruszewski, Wrocław-Warszawa-Kraków.

Szczepaniak M. (1995), Regulacja prawna statusu mniejszości narodowych. Węgierska propozycja wobec państw sqsiedzkich, w: Postzimnowojenna Europa. Ku jedności czy nowym podziałom?, (red.) T. Łoś-Nowak, Wrocław.

Thornberry P. (1991), International Law and minorities, Oxford.

Tomaszewski J. (1985a), Ojczyzna nie tylko Polaków, Warszawa.

Tomaszewski J. (1985b), Rzeczpospolita wielu narodów, Warszawa.

Tomaszewski J. (1997), Mniejszości narodowe w prawie polskim 1918-1939, „Więź”, nr 2.

Traktaty o przyjaźni i wspótpracy zawarte przez Polskę. Wybór dokumentów (2005), Wstęp i opracowanie A. Przyborowska-Klimczak, W. S. Staszewski, Lublin.

Ustawa z 5 czerwca 1998 r. o administracji rzqdowej w województwie (2001), Dz. U., Nr 80, poz. 872, z późn. zm.

Walter P. A. F. (1952), Race and culture relations, New York. 


\title{
STRESZCZENIE
}

Wielokrotnie podejmowano próby sformułowania definicji mniejszości narodowych i etnicznych. Kwestia ta zaprzątała uwagę licznych instytucji i organizacji międzynarodowych. Została uregulowana w Konwencji ramowej o ochronie mniejszości narodowych oraz Europejskiej Karcie Języków Regionalnych. W Polsce na straży praw mniejszości narodowych stoi dyspozycja art. 35 Konstytucji oraz uchwalona 6 stycznia 2005 r., a później nowelizowana Ustawa o mniejszościach narodowych $i$ etnicznych oraz języku regionalnym. W akcie tym jednak nie zdefiniowano pojęcia mniejszości, zaś treścią ustawy objęto jedynie niektóre z zamieszkujących w Polsce mniejszości narodowych. Znaczącym ograniczeniem ustawowym jest żądanie, aby przodkowie poszczególnych mniejszości zamieszkiwali obecne terytorium Rzeczpospolitej co najmniej od stu lat. Za mniejszości narodowe ustawodawca uznał jedynie dziewięć mniejszości narodowych oraz cztery mniejszości etniczne, przy czym w ustawie nie sprecyzowano wymogów różniących mniejszość narodową od etnicznej. Z dobrodziejstwa ustawy nie mogą, jak się okazuje, skorzystać przedstawiciele mniejszości wietnamskiej, francuskiej, amerykańskiej, greckiej, włoskiej i innych, dlatego że ustawodawca nie wymienił ich expressis verbis. Dyskusyjne jest przy tym, czy można uznać, że przedstawiciele wspomnianych mniejszości nie zamieszkiwali w przeszłości terytorium polskiego. Historia poświadcza, iż mieszkańcami Polski byli przecież jeszcze przed rozbiorami Włosi, Francuzi, Grecy, we Lwowie, Kamieńcu itd. Oczywiście nie mieszkali na tym obszarze Wietnamczycy czy Arabowie. Analiza ustawy wskazuje, że jest ona zgodna $\mathrm{z}$ aktami prawa międzynarodowego. Zauważyć jednak należy, że w chwili obecnej przedstawiciele różnych mniejszości, w tym także mieszkających w Polsce od setek lat, stają się obiektami ataków ze strony członków polskiego społeczeństwa. Dotyczy to Żydów, Tatarów, Arabów, Karaimów. Ataki te są bezpardonowe zwłaszcza wówczas, gdy przedstawiciele mniejszości nie należą do chrześcijan. Skonstatować należy niezrozumiałą obawę przed uchodźcami i złe traktowanie uchodźców także przez organy państwa, na co zwraca uwagę Rzecznik Praw Obywatelskich.

\section{NATIONAL MINORITIES AND POLAND'S SECURITY?}

\begin{abstract}
Numerous attempts to define national and ethnic minorities have been made. The provisions of the Framework Convention for the Protection of National Minorities and of the European Charter for Regional or Minority Languages have tried to regulate this issue. The rights of national minorities in Poland are protected by Article 35 of the Constitution and the Law on national and ethnic minorities and regional languages. However, this fails to define the notion of a minority and encompasses only certain national minorities living in Poland. Its legal scope is limited by the requirement that the ancestors of minorities have lived on the territory of Poland for at least one hundred years. The legislator recognizes only nine national minorities and four ethnic minorities, and fails to stipulate the conditions for differentiating national minorities from ethnic minorities. The provisions of the law cannot be invoked by the representatives of Vietnamese, French, American, Greek, Italian and other minorities since they are not explicitly referred to by the legislator.
\end{abstract}

